\title{
Melt inclusion constraints on volatile systematics and degassing history of the 2014-2015 Holuhraun eruption, Iceland
}

DOI:

10.1007/s00410-017-1434-1

\section{Document Version}

Accepted author manuscript

Link to publication record in Manchester Research Explorer

Citation for published version (APA):

Bali, E., Hartley, M. E., Halldórsson, S. A., Gudfinnsson, G. H., \& Jakobsson, S. (2018). Melt inclusion constraints on volatile systematics and degassing history of the 2014-2015 Holuhraun eruption, Iceland. Contributions to Mineralogy and Petrology, 173(9). https://doi.org/10.1007/s00410-017-1434-1

\section{Published in:}

Contributions to Mineralogy and Petrology

\section{Citing this paper}

Please note that where the full-text provided on Manchester Research Explorer is the Author Accepted Manuscript or Proof version this may differ from the final Published version. If citing, it is advised that you check and use the publisher's definitive version.

\section{General rights}

Copyright and moral rights for the publications made accessible in the Research Explorer are retained by the authors and/or other copyright owners and it is a condition of accessing publications that users recognise and abide by the legal requirements associated with these rights.

\section{Takedown policy}

If you believe that this document breaches copyright please refer to the University of Manchester's Takedown Procedures [http://man.ac.uk/04Y6Bo] or contact uml.scholarlycommunications@manchester.ac.uk providing relevant details, so we can investigate your claim.

\section{OPEN ACCESS}


MELT INCLUSION CONSTRAINTS ON VOLATILE SYSTEMATICS AND DEGASSING HISTORY OF THE 2014-2015 HOLUHRAUN ERUPTION, ICELAND

\author{
Bali, E. ${ }^{1}$, Hartley, M.E. ${ }^{2}$, Halldórsson, S.A. ${ }^{1}$, Gudfinnsson, G.H. ${ }^{1}$, Jakobsson, S. $^{1}$
}

${ }^{1}$ Nordic Volcanological Center, Institute of Earth Sciences, University of Iceland, 107, Reykjavík, Iceland

${ }^{2}$ School of Earth \& Environmental Sciences, University of Manchester, M13 9PL, Manchester, UK

Corresponding author: E. Bali, e-mail: eniko@ hi.is, phone: +354-525 4480, Fax: +354 562 9767

10 figures and 2 tables, 4 supplementary tables + Supplementary material

Acknowledgements: We are grateful for the sampling work carried out by the 2014-2015 Holuhraun eruption team (University of Iceland) led by Morten S. Riishuus, Ármann Höskuldsson and Thorvaldur Thordarson, and by a team of researchers from the UK led by Evgenia Ilyinskaya. We are also grateful to the Civil Protection Department of the National Commissioner of the Icelandic Police for making the work in the field possible. This work was financially supported by Natural Environment Research Council grants [NE/M021130/1] and [IMF548/1114] and by the DFG core facility for high pressure research programme at the Bayerisches Geoinstitut, University of Bayreuth. We thank Richard Hinton and Cees-Jan de 
Hoog for their assistance with the SIMS analyses and Tamás Váczi (Eötvös University, Budapest) for his assistance during the Raman analyses. 


\section{ABSTRACT:}

The mass of volatiles emitted during volcanic eruptions is often estimated by comparing the volatile contents of undegassed melt inclusions, trapped in crystals at an early stage of magmatic evolution, with that of the degassed matrix glass. Here we present detailed characterisation of magmatic volatiles $\left(\mathrm{H}_{2} \mathrm{O}, \mathrm{CO}_{2}, \mathrm{~S}, \mathrm{Fl}\right.$ and $\left.\mathrm{Cl}\right)$ of crystal-hosted melt and fluid inclusions from the 2014-2015 Holuhraun eruption of the Bárðarbunga volcanic system, Iceland. Based on the ratios of magmatic volatiles to similarly incompatible trace elements, the undegassed primary volatile contents of the Holuhraun parental melt are estimated at 1500-1700 ppm $\mathrm{CO}_{2}, 0.13-0.16 \mathrm{wt} \% \mathrm{H}_{2} \mathrm{O}, 60-80 \mathrm{ppm} \mathrm{Cl}, 130-240 \mathrm{ppm} \mathrm{F}$ and 500-800 ppm S. High-density fluid inclusions indicate onset of crystallisation at pressures $\geq 0.4 \mathrm{GPa}(\sim 12$ $\mathrm{km}$ depth) promoting deep degassing of $\mathrm{CO}_{2}$. Prior to the onset of degassing, the melt $\mathrm{CO}_{2}$ content may have reached $3000-4000$ ppm, with the total magmatic $\mathrm{CO}_{2}$ budget estimated at 23-55 Mt. $\mathrm{SO}_{2}$ release commenced at $0.12 \mathrm{GPa}(\sim 3.6 \mathrm{~km}$ depth), eventually leading to entrapment of $\mathrm{SO}_{2}$ vapour in low-density fluid inclusions. We calculate the syn-eruptive volatile release as 22.2 Mt of magmatic $\mathrm{H}_{2} \mathrm{O}$, 5.9-7.7 $\mathrm{Mt} \mathrm{CO}_{2}$, and 11.3 Mt of $\mathrm{SO}_{2}$ over the course of the eruption; $\mathrm{F}$ and $\mathrm{Cl}$ release were insignificant. Melt inclusion constraints on syneruptive volatile release are similar to estimates made during in situ field monitoring, with the exception of $\mathrm{H}_{2} \mathrm{O}$, where field measurements may be heavily biased by the incorporation of meteoric water.

Keywords: degassing, Iceland, Holuhraun 2014-2015, melt inclusion, mantle volatiles 


\section{INTRODUCTION:}

Dissolved volatiles in magmas have profound effects on fundamental melt parameters, such as melt density and viscosity (e.g. Giordano et al. 2008; Mysen 2012; Baasner et al. 2013), which in turn influence how silicate melts are transported through the crust and the style of volcanic eruption observed at the Earth's surface. Volatile outgassing during large basaltic eruptions may also have a significant impact on the local environment and/or the global climate (e.g. Sigurdsson 1990; Black et al. 2012; Schmidt et al. 2010; Jones et al. 2016). For example, the large flood basalt eruption of Laki in 1783-84 AD is thought to have been responsible for a $\sim 1.3{ }^{\circ} \mathrm{C}$ temperature drop in the northern hemisphere, while severe atmospheric conditions were responsible for a famine that led to the death of some $20 \%$ of the Icelandic population (Thordarson and Self, 2003).

The 2014-15 Holuhraun eruption is the first moderate- to large-scale flood basalt (i.e. $>1 \mathrm{~km}^{3}$ ) eruption in a divergent tectonic environment that has been observed, monitored, and sampled in real time (Fig. 1, Table S1). It therefore offers a unique opportunity to compare petrological constraints on subsurface degassing and atmospheric volatile loading with in situ monitoring of outgassed volatiles and changes in plume chemistry (Gíslason et al. 2015; Gauthier et al. 2016). In this study, we present detailed characterisation of magmatic volatiles in crystal-hosted melt and fluid inclusions collected over the entire duration of the Holuhraun eruption. We use these data to evaluate temporal variability of volatile release during the eruption, the effects of magma mixing, fractional crystallisation and crustal contamination on the magmatic volatile budget, as well as estimation of depths of melt and fluid inclusion trapping within the magmatic system. We use volatile-trace element ratios to constrain volatile heterogeneity in primary melts supplied to the system, and estimate volatile contents in the Holuhraun mantle source. 
Our results reveal good agreement with estimates on volatile release derived from in situ measurements of the plume chemistry. This demonstrates the validity of melt inclusion studies in reconstructing pre- and syn-eruptive volatile budgets and supports the notion that this method is indeed applicable to historic and ancient eruptions, both in Iceland and at other volcanic settings. These results also suggest that there was no accumulation of a gas phase prior to eruption.

\section{Sample preparation and analytical techniques}

During the eruption fresh tephra samples were collected at regular intervals from sites close to the main eruptive vent (Fig. 1). This study focuses on 10 of these tephra samples, the earliest of which was collected at the start of the eruption on 31 August 2014, and the latest of which was collected on 22 of January 2015, towards the end of the eruption (Fig. 1, TableS1). During this period, the lava effusion rate was changing significantly (Fig.1) and the intense lava fountaining of early September 2014 was not observed in the later stages of the eruption. Throughout the eruption, activity was dominated by the emplacement of lava flows (Pedersen et al., 2017 and references therein).

Plagioclase, olivine and clinopyroxene macrocrysts range 0.5 to $1.7 \mathrm{~mm}$ in the size, containing naturally quenched vitreous melt inclusions, were hand-picked from crushed tephra samples and doubly polished. Selected melt and fluid inclusions were then analysed by Fourier transform infrared spectroscopy (FTIR) and micro-Raman spectroscopy.

$\mathrm{H}_{2} \mathrm{O}$ and $\mathrm{CO}_{2}$ contents of groundmass glasses and some melt inclusions were determined by Fourier Transform Infrared (FTIR) spectroscopy at the Institute of Earth Sciences, University of Iceland. The composition and the density of fluid inclusions within minerals, and melt inclusion-hosted bubbles, were analysed by confocal Raman spectroscopy at the Bayerisches Geoinstitut, Bayreuth and at the ELTE TTK FFI Instruments Center of the 
Eötvös University, Budapest, Hungary. Following FTIR and Raman analyses, crystals were individually re-polished to expose the melt inclusions at the surface, and re-mounted in Epothin epoxy resin for analysis by ion- and electron microprobe. Electron microprobe analyses (EPMA) of major and minor elements as well as $\mathrm{S}$ and $\mathrm{Cl}$ in groundmass glasses and melt inclusions were acquired with the JEOL JXA-8230 Superprobe at the Institute of Earth Sciences, University of Iceland. Secondary ionization mass spectrometry (SIMS) was applied to determine volatile $\left(\mathrm{H}_{2} \mathrm{O}, \mathrm{CO}_{2}, \mathrm{~F}\right)$ and trace element contents in both melt inclusions and matrix glasses. These analyses were performed on the Cameca ims-4f ion microprobe at the University of Edinburgh. Full descriptions of all analytical techniques are provided as supplementary material (S1).

\section{RESULTS:}

\section{Petrography of melt and fluid inclusions and their host minerals:}

Holuhraun tephra samples contain large $(>1 \mathrm{~mm})$ macrocrysts of plagioclase, olivine and augite; smaller microphenocrysts ( $<1 \mathrm{~mm}$ diameter); and polymineralic glomerocrysts (Halldórsson et al. this issue). Most glass fragments recovered from the tephra are highly vesicular, but some non-vesicular fragments also occur. Sulphide globules are commonly observed in the groundmass glass of tephra samples (Halldórsson et al. this issue). Melt and fluid inclusions are common in plagioclase macrocrysts and microphenocrysts, and are occasionally found in olivine and clinoyroxene macrocrysts (Fig. 2a-f). Sulphide globules occur as rare inclusions in microphenocrysts. On the basis of petrographic observations, we have identified the following inclusion types:

1) Large-diameter $(>100 \mu \mathrm{m})$, spherical or negative crystal-shaped melt inclusions, with or without a fluid phase, located in macrocryst cores (Fig. 2a). These inclusions may be found in isolation or in clusters of a few inclusions, and are 
most commonly found in plagioclase macrocrysts. Some of these large inclusions are cracked.

2) Medium-diameter $(20-100 \mu \mathrm{m})$, spherical to irregularly shaped melt inclusions in sieve-textured plagioclase cores, which are generally surrounded by an inclusionfree rim (Fig. 2b). The host plagioclase cores are often heterogeneous, exhibiting complex zoning patterns (Fig 2b). In several cases, the melt inclusions are associated with fluid inclusions (Fig. 2c).

3) Small-diameter $(<30 \mu \mathrm{m})$, irregularly shaped melt inclusions trapped in macrocryst rims and in microphenocrysts, occasionally with other mineral and fluid inclusions (Fig. 2d). This inclusion type occurs in all silicate phases, but is less common in olivine.

4) Pseudosecondary inclusion trails (Roedder 1984; Fig. 2e) containing both fluid and melt inclusions, found in plagioclase macrocryst cores, which are surrounded by melt inclusion-rich zones.

5) Fluid inclusions $(<5 \mu \mathrm{m}$ diameter $)$ along healed fractures in plagioclase macrocrysts or in clusters in mineral cores (Fig. 2f).

6) Sulphide inclusions in microphenocrysts (Fig. 2g)

\section{Major and trace element composition of melt inclusions:}

Variation of selected major and trace elements in melt inclusions, corrected for post entrapment processes (PEC), are shown in Figure 3 (see full PEC-corrected dataset in Table S2). The procedure of PEC correction and the comparison of corrected and uncorrected inclusion compositions are discussed in detail in an accompanying paper by Hartley et al. (this issue). Here we only assess the most important elemental characteristics. We also plot calculated liquid line of descents (LDDs) in these diagrams, which were determined by the 
Petrolog3 program package of Danyushevsky \& Plechov (2011). We used forward modelling and the average composition of the most primitive melt inclusions as a starting composition. Details of calculation procedure are in Supplementary material 4.

Melt inclusions cover a very large compositional range compared to both groundmass glass and bulk rock compositions (the latter are discussed in detail by Halldórsson et al., this issue). The most evolved melt inclusions are similar in composition to the most evolved groundmass glasses, whereas the most primitive inclusions have PEC-corrected $\mathrm{MgO}$ contents up to 10.04 wt $\%$ and $\mathrm{Mg \#}$ (calculated as $100 * \mathrm{Mg} /(\mathrm{Mg}+\mathrm{Fe}(\mathrm{t}))$ of $~ 70$. In general, PECcorrected melt inclusions and groundmass glasses follow tight compositional trends with decreasing $\mathrm{CaO}$ and $\mathrm{Al}_{2} \mathrm{O}_{3}$ and increasing $\mathrm{K}_{2} \mathrm{O}$ and $\mathrm{TiO}_{2}$ contents with decreasing $\mathrm{MgO}$ (Fig. 3). The moderately to highly evolved glass compositions $(\mathrm{MgO}<8.2 \mathrm{wt} \%)$ in this sample set overlap with the compositions of Holocene tephra glasses from the Bárðarbunga system analysed by Óladóttir et al. (2011). The most primitive melt inclusions are similar in composition to glasses collected from tholeiitic picrite formations from the active rift zone in Iceland (e.g.: Breddam, 2002). A few melt inclusions are sligthly off the main compositional trends in Figure 3a-d (Table S2). These compositions might indicate disequilibrium melt compositions, perhaps due to boundary layer effects (e.g.: Faure and Schiano, 2005; Baker, 2008), as they also fall outside the natural variation of Icelandic tholeiitic glasses.

Figure $3 \mathrm{e}-\mathrm{g}$ shows the variation of selected trace elements as a function of $\mathrm{MgO}$. These elements were chosen as they are commonly used as proxies of volatile abundance because they show similar incompatibility to certain volatiles during mantle melting and fractional crystallisation. $\mathrm{Nb}$ is commonly used as a proxy for $\mathrm{CO}_{2}, \mathrm{Ce}$ for $\mathrm{H}_{2} \mathrm{O}, \mathrm{Nd}$ for $\mathrm{F}$ (e.g. Michael, 1995, Saal et al., 2002, Shimizu et al., 2016 and references therein). All these trace elements show clear negative correlations with $\mathrm{MgO}$ as expected during a process dominated by fractional crystallisation. The variation around these trends is however larger than the $2 \sigma$ 
analytical uncertainty in each analysed trace element. In particular, the compositions of several melt inclusions (Table S2) fall significantly above or below the chemical trends defined by the main population of inclusions. Therefore, we omit these inclusion compositions from further discussion.

\section{Volatile abundance in melt inclusions:}

$\mathrm{CO}_{2}$

Carbon dioxide contents of silicate melt inclusions might be concentrated in their bubble phases (Fig. 2a) as $\mathrm{CO}_{2}$ can exsolve rapidly upon magma ascent (e.g. Métrich and Wallace 2008, Hartley et al. 2014). Although many of the Holuhraun melt inclusions contain bubbles that generally occupy $\sim 1$ to 5 vol.\% of the total inclusion volume (Fig. 2a), microRaman spectroscopy reveals no detectable volatile species in most cases. This indicates that these bubbles are true shrinkage bubbles formed in response to contraction of the melt phase during rapid cooling, with insufficient time for volatile species to diffuse from melt to vapour phase (e.g. Pichavant et al. 2013). In a single exception, $\mathrm{CO}_{2}$ was detected in an inclusionhosted bubble. The mass of $\mathrm{CO}_{2}$ in this bubble was determined from the bubble size and fluid density (e.g. Steele-Macinnis et al. 2011), and added to the glass composition to obtain the true $\mathrm{CO}_{2}$ content of the melt (Table S2).

The total $\mathrm{CO}_{2}$ concentrations in Holuhraun PEC-corrected melt inclusions vary between 23 and 1640 ppm, with one exception where the inclusion contains 3900 ppm (Fig. $4 \mathrm{a}$, Table S2). There is a weak positive correlation $\left(\mathrm{R}^{2}=0.41\right)$ between melt inclusion $\mathrm{MgO}$ (in wt.\%) and $\mathrm{CO}_{2}$ (Fig. 4a). No systematic difference was observed in $\mathrm{CO}_{2}$ contents of melt inclusions trapped in different minerals. The total $\mathrm{CO}_{2}$ contents are similar to those observed in plagioclase-hosted melt inclusions from the 10 ka Grímsvötn tephra series (up to 2070 ppm

- Neave et al. 2015), but lower than those measured in olivine-hosted inclusions from the Laki 1783-84 eruption (up to 4770 ppm - Hartley et al. 2014) (Fig. 4a). We observe no variation in 
melt inclusion $\mathrm{CO}_{2}$ content with time and note that both $\mathrm{CO}_{2}$-rich and $\mathrm{CO}_{2}$-poor inclusions were brought to the surface during the entire eruption (Table S2). Groundmass glass $\mathrm{CO}_{2}$ concentrations are generally below $100 \mathrm{ppm}$ and in some cases below the $\sim 20 \mathrm{ppm}$ detection limit of the SIMS analyses. Holuhraun melt inclusions preserve a negative correlation between $\mathrm{CO}_{2}$ and $\mathrm{Nb}$ (Fig. 4b), similar to that observed in olivine-hosted melt inclusions from Skuggafjöll, a subglacial eruption on the southern branch of the Bardarbunga volcanic system (Neave et al. 2015).

A few primitive and moderately evolved melt inclusions (with $\mathrm{Nb}<8 \mathrm{ppm}$ ) have $\mathrm{CO}_{2} / \mathrm{Nb}$ ratios in the range of 314 to 505 which is expected for near-primary silicate melts derived from depleted mantle (Fig. 4b, c) (Hauri et al. 2002; Rosenthal et al. 2015). However, most melt inclusions fall off this field (in gray) towards high $\mathrm{Nb}$ contents, coupled with low $\mathrm{CO}_{2}$ (Fig. $4 \mathrm{~b}$ c).

\section{$\mathrm{H}_{2} \mathrm{O}$}

Melt inclusion $\mathrm{H}_{2} \mathrm{O}$ contents vary between 0.07 and 0.60 wt.\% (Fig. 5 and FigS2b). Groundmass glasses show similar variation, but two groups can be distinguished. The highly vesicular, evolved groundmass glasses generally have $\mathrm{H}_{2} \mathrm{O}$ contents $<0.2$ wt.\%, whereas the non-vesicular glass fragments have higher $\mathrm{H}_{2} \mathrm{O}$ contents. There is no correlation between $\mathrm{H}_{2} \mathrm{O}$ and other major or trace elements in melt inclusions (Fig. 5, Table S2). However, melt inclusions in tephras erupted between 31 August and 8 September (Fig. 5, dark symbols), show a weak positive correlation with $\mathrm{K}_{2} \mathrm{O}\left(\mathrm{r}^{2}=0.47\right)$. When all melt inclusions in our dataset are considered this correlation is not preserved. Both $\mathrm{H}_{2} \mathrm{O}$-rich and $\mathrm{H}_{2} \mathrm{O}$-poor inclusions are present throughout the course of the eruption (Table S2). Measured $\mathrm{H}_{2} \mathrm{O}$ concentrations are similar to those in olivine- and plagioclase-hosted melt inclusions from Laki (0.07-0.8 wt.) \% and Grímsvötn (0.2-0.7 wt.\%) (Hartley et al. 2014; Neave et al. 2015) (Fig. 6).

\section{Halogens ( $\mathrm{Cl}$ and $\mathrm{F})$}


Holuhraun melt inclusions and groundmass glasses display similar $\mathrm{Cl}$ contents of 16$148 \mathrm{ppm}$ in PEC-corrected melt inclusions and 0-150 ppm in the groundmass glasses (Table $\mathrm{S} 2$, Figure 6). These concentrations are similar to the lower estimates of $\mathrm{Cl}$ contents in fresh MORB glasses (1-400 ppm; Saal et al. 2002; Michael and Cornell, 1998). We observe no correlation between melt inclusion $\mathrm{Cl}$ content and $\mathrm{MgO}$, but note that the most primitive melt inclusions have $\mathrm{Cl}$ concentrations $\sim 47-71 \mathrm{ppm}$ (Fig. 6a). In contrast, more evolved melt inclusions are characterized by a large range of values, from 16 to $148 \mathrm{ppm}$. All but a few of the most primitive melt inclusions have $\mathrm{Cl} / \mathrm{K}$ ratios similar to Mid-Oceanic Ridge Basalts (MORB) (Fig. 6b.).

PEC-corrected melt inclusion and groundmass glass F contents vary between 123 and 790 ppm, with mean $\mathrm{F}$ concentrations of 459 ppm for melt inclusions and 413 ppm for groundmass glasses (Fig. 7, Table S2). Some of these values are slightly higher than those observed in fresh MORB glasses (100 to $600 \mathrm{ppm}$ ). F/Nd ratios in most melt inclusions are higher than those observed in N-MORB, and some are higher than E-MORB (Saal et al. 2002, Oppenheimer 2004) (Fig. 7b). The average F/Nd ratio of melt inclusions trapped in olivine and clinopyroxene is $31 \pm 5.2(1 \sigma)$ which is similar to that observed in groundmass glasses $(29 \pm 5.3,1 \sigma)$, whereas the melt inclusions trapped in plagioclase show higher average ratios (48) and larger variability $(1 \sigma$ standard deviation $=25)$.

Fluorine is weakly negatively correlated with $\mathrm{MgO}$ in melt inclusions collected during the first 10 days of the eruption (dark symbols in Fig. $6 b, r^{2}=0.495$ ), but this correlation does not hold when considering the entire melt inclusion dataset (Fig. 7a).

\section{Sulphur}

The most primitive Holuhraun melt inclusions contain 680 to $720 \mathrm{ppm} \mathrm{S}$, rising to $1600 \mathrm{ppm}$ in the most evolved melt inclusions (Fig. 8a, Table S2). As expected for a relationship governed by fractional crystallisation, we observe a strong negative correlation 
between melt inclusion $\mathrm{MgO}$ and sulphur contents (Fig. 8a). Many tephra glasses contain 400 ppm S, presumably due to degassing of sulphur during magma ascent and eruption (Fig. 8a, Table S2). Sulphur concentrations in Holuhraun melt inclusions and matrix glasses are similar to those observed in erupted products from the 2011 Grímsvötn (up to 1980 ppm Sigmarsson et al. 2013), 1783-84 Laki (up to 1970 ppm - Métrich et al. 1991) and 934-940 Eldgjá eruptions (up to 2425 ppm - Thordarson et al. 2001). Most melt inclusions display S/Dy ratios similar to unaltered MORB (150-310, Saal et al. 2002; Workman et al. 2006) (Figure 8b).

\section{Fluid inclusions}

The compositions of 31 fluid inclusions, hosted in 11 plagioclase macrocrysts from 4 tephra samples erupted between 31 August and 12 November 2014, were determined by Raman spectroscopy. Twenty-two fluid inclusions were pure $\mathrm{CO}_{2}$, whereas 9 also contained $\mathrm{SO}_{2}$ (Table S3). No other volatile species were detected in the micro-Raman spectra (Table S3, Fig S3). All measurements were conducted at room temperature and although $\mathrm{H}_{2} \mathrm{O}$ was not detected in our analyses, we cannot rule out the possible presence of small volumes of liquid $\mathrm{H}_{2} \mathrm{O}$ at the inclusion-macrocryst interface (e.g., Berkesi et al. 2009; Esposito et al. 2016).

Fluid inclusion densities were determined on the basis of the distance between the two $\mathrm{CO}_{2}$ Raman bands around 1250 and $1450 \mathrm{~cm}^{-1}$, referred to as the Fermi diad (Table 1). The relationship between the Fermi diad spacing $(\Delta)$ and fluid density has been calibrated by various groups (Frezzotti et al. 2012 and references therein). In this study, we adopt the Fall et al. (2011) densimeter, which is calibrated for pure $\mathrm{CO}_{2}$ fluid inclusions. The assumption of a pure $\mathrm{CO}_{2}$ fluid phase is likely to be valid for high-density fluid inclusions in Holuhraun macrocrysts, which contain only $\mathrm{CO}_{2}$ peaks in their Raman spectra. The highest $\mathrm{CO}_{2}$ density 
determined was $0.703 \mathrm{~g} / \mathrm{cm}^{3}$. Some of the low-density inclusions $\left(0\right.$ to $\left.0.26 \mathrm{~g} / \mathrm{cm}^{3}\right)$ have $\mathrm{SO}_{2}$ peaks in their Raman spectra (Table S3, Fig. S3), but the presence of minor volumes of additional vapour phases has been shown to have no significant effect on $\mathrm{CO}_{2}$ densities determined by this method (Frezzotti and Peccerillo, 2007; Frezzotti et al. 2012).

\section{DISCUSSION:}

\section{Magma storage conditions}

Magma storage conditions preceding volcanic eruptions are generally estimated using one or more geothermobarometers. Our dataset allows us to compare results based on the following of geobarometers: 1) Clinopyroxene-melt barometry (Neave and Putirka, 2017) that estimates the crystallisation pressure (and temperature) of clinopyroxenes in the volcanic system, with an uncertainty of $\pm 0.14 \mathrm{GPa}$ (results discussed in details in the accompanying paper by Halldórsson et al. this volume); 2) Silicate melt barometry (Yang et al., 1996) that gives an estimation of the pressure at which melt with a particular composition is multiply saturated in olivine, plagioclase and augite (commonly referred as to the OPAM barometer) with an uncertainty of $\pm 0.13 \mathrm{GPa}$ (results discussed in details in the accompanying paper by Hartley et al. this volume). This barometer can only be applied if the melt is saturated in all three mineral phases; if this is not the case, the barometer will yield erroneous results; 3) Fluid saturation pressure of silicate melts (e.g. Dixon et al. 1995; Shishkina et al. 2010), which allows the estimation of the pressure of melt inclusion entrapment with an uncertainty of $\sim 15 \%$ when the melt was saturated in $\mathrm{CO}_{2} \pm \mathrm{H}_{2} \mathrm{O}$ at the time of inclusion trapping. If the melt is fluid undersaturated, this method underestimates the true melt inclusion entrapment pressures; 4) Fluid inclusion barometry that gives an estimation of the entrapment pressure of fluid inclusions with an estimated uncertainty of $\pm 0.03 \mathrm{GPa}$. 
Here we discuss in detail the results of fluid inclusion barometry and barometry based on fluid saturation pressures in melt inclusions and groundmass glasses. We compare these pressure estimates with those obtained by clinopyroxene-melt and OPAM barometry and discuss the possible reasons for discrepancies between these methods. Finally we interpret our data in light of geophysical observations.

\section{Fluid inclusion barometry in plagioclase macrocrysts:}

Assuming that the temperature of the system at the time of inclusion trapping is known, entrapment pressures of $\mathrm{CO}_{2}$ fluid inclusions can be estimated using a $\mathrm{CO}_{2}$ equation of state (Sterner and Pitzer, 1994). The temperature can be estimated from co-existing melt inclusions and silicate melt thermometry (e.g. equation 15 in Putirka, 2008). The combined error on the fluid density and temperature is estimated to be $<18 \%$, which propagates to an uncertainty of $\pm 0.03 \mathrm{GPa}$ or less for the entrapment pressure estimation. We note, however, that these estimates must be regarded as minimum pressures of fluid inclusion entrapment, since the volume of a fluid inclusion may undergo post-entrapment modification in response to the stretching or contraction of the host mineral, and/or the fluid density may decrease following decrepitation during magma ascent (Hansteen and Klugel, 2008; and references therein).

The highest measured fluid inclusion density in a fluid inclusion trapped along with melt inclusions (in a sample from 31 August 2014) was $0.703 \mathrm{~g} / \mathrm{cm}^{3}$ (Table S3). Using the major element composition of the co-existing melt inclusions and equation 15 in Putirka (2008), an inclusion entrapment temperature of $1210 \pm 46{ }^{\circ} \mathrm{C}$ was determined, resulting in an entrapment pressure of $0.394-0.423 \mathrm{GPa}$ (Table S3). Assuming a mean crustal density of 2.86 $\mathrm{g} / \mathrm{cm}^{3}$, this pressure corresponds to a minimum fluid inclusion entrapment depth of $13-14 \mathrm{~km}$. This estimate falls within the depth range calculated with clinopyroxene-melt and olivine- 
plagioclase-augite-melt (OPAM) barometries (Fig. 9a and Halldórsson et al., Hartley et al. both this issue), and is similar to geodetic results suggesting a deflating source beneath Bárðarbunga at 8-12 km depth (Gudmundsson et al. 2016). Most fluid inclusions have lower densities and were trapped at significantly shallower depths ( 3 to $5 \mathrm{~km}$ ), which agrees well with recorded seismicity between Bárðarbunga volcano and the eruption site $(3-9 \mathrm{~km}$; Sigmundsson et al. 2015).

\section{Volatile saturation pressures in melt inclusions:}

Volatile solubility in silicate melts, especially that of $\mathrm{CO}_{2}$, is strongly pressuredependent (Dixon et al. 1995; Shishkina et al. 2010). Volatile saturation models can therefore be used to estimate pressures of melt inclusion trapping. However, if melt inclusions trap volatile-undersaturated melts, these models provide only minimum estimates of inclusion trapping pressures.

The presence of high-density fluid inclusions suggests that the Holuhraun melt became $\mathrm{CO}_{2}$-saturated at mid- to lower-crustal pressures in excess of $0.4 \mathrm{GPa}$. Volatile saturation models for mafic melts suggest maximum melt $\mathrm{CO}_{2}$ contents of 2000-4000 ppm at fluid saturation under these conditions (Newman and Lowenstern, 2002, Shishkina et al. 2014). One of the analysed melt inclusions displayed notably high $\mathrm{CO}_{2}$ contents of $3900 \mathrm{ppm}$. This inclusion, however, also had anomalously high $\mathrm{CO}_{2} / \mathrm{Nb}$ (760) suggesting that the measurement might have been contaminated by the content of its vapour phase. Some melt inclusions with $\mathrm{CO}_{2} / \mathrm{Nb}$ ratios within 505 \pm 158 (Rosenthal et al., 2015), might have trapped fluid undersaturated melt preserving the $\mathrm{CO}_{2} / \mathrm{Nb}$ ratio of the 'primary melt' (see in details below). The pressures calculated based on these volatile contents do represent somewhat lower pressures than the true entrapment pressure. Most melt inclusions, on the other hand, 
trapped either $\mathrm{CO}_{2}$-undersaturated or partially degassed melts with $\mathrm{CO}_{2}$ contents of less than 1700 ppm (Fig. 4a, b).

We calculated $\mathrm{CO}_{2}$ saturation pressures for Holuhraun melt inclusions both by adopting the calibration of Shishkina et al. (2014) and the VolatileCalc model (Newman and Lowenstern, 2002) (Table S2). The calculated $\mathrm{CO}_{2}$ saturation pressures range between 0.009 and $0.278 \mathrm{GPa}$ (mean $0.117 \pm 0.049 \mathrm{GPa}$ ) based on Shishkina et al. (2014) calibration and 0.005 and $0.337 \mathrm{GPa}$ (mean $0.150 \pm 0.073 \mathrm{GPa}$ ) based on the VolatileCalc model (Fig. 9). When all melt inclusions are considered, there is a weak positive correlation $\left(r^{2}=0.44\right)$ between $\mathrm{MgO}$ and the calculated volatile saturation pressures (Fig. 9b). When those melt inclusions that are most probably fluid undersaturated (indicated in green in Fig. 9b) are omitted, because these values do not represent real entrapment pressures, the correlation coefficient $\left(\mathrm{r}^{2}\right)$ between $\mathrm{MgO}$ and fluid saturation pressure drops below 0.3.

The most evolved melt inclusions $(\mathrm{MgO}<7.0)$ record, low pressures by both VolatileCalc and olivine-plagioclase-augite-melt (OPAM, calculated on PEC-corrected melt inclusion compositions) models (Yang et al., 1996): the calculated pressures are indistinguishable within the uncertainties of the two barometers (Fig. 9b and Hartley et al., this volume). Therefore, we can be confident that these evolved melt inclusions were trapped at relatively shallow depths of 0 to $9 \mathrm{~km}$, which is consistent with the estimated depth of dyke intrusion recorded by seismicity (3-9 km; Sigmundsson et al. 2015).

There is larger difference between the results of the two geobarometers among the more primitive melt inclusions $(\mathrm{MgO}>7.0 \mathrm{wt} \%)$, for which OPAM barometry shows on an average $0.170 \mathrm{GPa}$ higher entrapment pressures than the VolatileCalc model. Moreover, the difference increases towards more primitive melt inclusions. A few of the melt inclusions, where relatively large discrepancies are observed between the results of the two models (Fig. $9 \mathrm{~b}$ and Table S2), were cracked and may have lost some of their $\mathrm{CO}_{2}$. Other melt inclusions 
did not show obvious signs of decrepitation based on microscopic observations. However, this does not mean that those melt inclusions have not lost any $\mathrm{CO}_{2}$. For example, Viti and Frezzotti (2001) have shown that fluid inclusions are commonly connected to dislocations in minerals which are observable only by transmission electron microscopy. These dislocations might provide pathways of fluid leakage, and thus fluid inclusions always record minimum pressure of inclusion trapping. As far as we know, this process has not been studied in detail for the case of silicate melt inclusions, but we expect that similar processes are operating.

As clinopyroxene-melt and OPAM barometries in the same set of samples show nearly identical crystallisation conditions (blue bars in Fig. 9a), we suggest that these barometers give a better estimate of the initial magma storage conditions than the fluid saturation pressures in melt inclusions. The depth of lateral magma transport, however, coincides with the pressure range recorded by the volatile content of melt inclusions. Thus, we suggest that at least some of the melt inclusions might have partially re-equilibrated with their external environment during this transportation process. This is supported by the low correlation coefficient between the $\mathrm{MgO}$ and $\mathrm{CO}_{2}$ contents in the melt inclusions. Volatile saturation pressures therefore provide only a robust minimum estimate of the pressures of melt inclusion trapping in the Holuhraun magmatic system, and most probably underestimate the true melt inclusion entrapment pressures.

\section{Estimation of primary volatile contents}

The PEC-corrected major element compositions of the most primitive melt inclusions suggest that these melt compositions $(\mathrm{MgO} \sim 10 \mathrm{wt} \%$ and $\mathrm{Mg \#} 70)$ are approaching the expected compositions of Icelandic primary mantle melts. The addition of $5 \mathrm{wt} \%$ equilibrium olivine to the average composition of the five most primitive melt inclusions will result in a

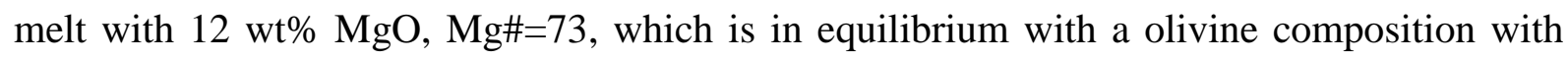


Fo=91 (according to the olivine-melt model of both Danyushevsky, 2001 and Langmuir et al., 1992). We did not consider adding plagioclase to the primitive melt inclusion compositions because this would generate a primary melt with unrealistically high $\mathrm{Al}_{2} \mathrm{O}_{3}$ content compared to the most primitive Icelandic tholeiites (Fig. 2). The resulting melt composition (Table S4) is similar to the "depleted end-member" estimates for the Northern Volcanic Zone of Iceland by Shorttle and Maclennan (2011). Using the trace element partition coefficients of O'Neill and Jenner (2012) and White (2013), the calculated trace element contents in this primary melt are as follows: $2.7 \mathrm{ppm} \mathrm{Nb}, 6.7 \mathrm{ppm} \mathrm{Ce}, 5.1 \mathrm{ppm} \mathrm{Nd}$ and $1.8 \mathrm{ppm}$ Dy. (A detailed description of the crystallisation modelling is provided in the supplementary material.) These trace element contents are used to estimate the primary volatile abundance in the Holuhraun magma based on the volatile-trace element ratios established in the following paragraphs.

$$
\mathrm{CO}_{2}:
$$

Undegassed silicate melt inclusions related by fractional crystallisation are expected to exhibit positive correlations between $\mathrm{CO}_{2}$ and similarly incompatible trace elements, such as $\mathrm{Nb}$ or Ba (e.g. Saal et al. 2002). Indeed, recent experimental work indicates that $\mathrm{CO}_{2} / \mathrm{Nb}$ and $\mathrm{CO}_{2} / \mathrm{Ba}$ ratios remain nearly constant during mantle melting and fractional crystallisation (Rosenthal et al. 2015). Assuming that the $\mathrm{CO}_{2} / \mathrm{Nb}$ or $\mathrm{CO}_{2} / \mathrm{Ba}$ of the primary melt is reasonably well established, $\mathrm{Nb}$ or $\mathrm{Ba}$ contents of basalts can be used as a proxy for the undegassed $\mathrm{CO}_{2}$ contents of silicate melts. Undegassed primary melts derived from a depleted mantle source are expected to display $\mathrm{CO}_{2} / \mathrm{Ba}=133 \pm 44$ and $\mathrm{CO}_{2} / \mathrm{Nb}=505 \pm 158$ (Rosenthal et al. 2015). Hauri et al. (2002) suggested a lower $\mathrm{CO}_{2} / \mathrm{Nb}$ of $314 \pm 125$ for Icelandic mantlederived melts, whereas recently Schipper et al. (2016) suggested somewhat higher $(\geq 590)$ parental $\mathrm{CO}_{2} / \mathrm{Nb}$ ratios for the southernmost part of the EVZ. We use the measured $\mathrm{Nb}$ contents and $\mathrm{CO}_{2} / \mathrm{Nb}$ ratios of 505 and 314 to calculate undegassed $\mathrm{CO}_{2}$ contents for each of the Holuhraun melt inclusions (Table S2). In Figure 4a we superimpose two trajectories, 
indicative of fractional crystallisation trends following fixed $\mathrm{CO}_{2} / \mathrm{Nb}$ ratios at 505 and 314 (see modelling details in supplementary material). It is clear that most of the Holuhraun inclusions trapped melts that are at least partially degassed, or have experienced decrepitation and $\mathrm{CO}_{2}$ loss during magma ascent (Maclennan, 2017), with the exception of some of the moderately to most primitive melt inclusions ( $\mathrm{MgO}>8$ wt.\%) with $\mathrm{CO}_{2} / \mathrm{Nb} 500$ (Fig. 4a). This indicates that $\mathrm{CO}_{2}$ contents of $\sim 1500-1700 \mathrm{ppm}$, hosted by some of the most primitive melt inclusions, may represent a near-primary $\mathrm{CO}_{2}$ content in the Holuhraun melt before the onset of degassing. Based on the relationship between $\mathrm{MgO}-\mathrm{Nb}-\mathrm{CO}_{2}$ (Fig. 4a) the experimentally derived $\mathrm{CO}_{2} / \mathrm{Nb}=505$ might be close to the maximum ratio in the Holuhraun parental melt whereas the $\mathrm{CO}_{2} / \mathrm{Nb}=314$ might be close to the minimum. Using the $\mathrm{Nb}$ content of the calculated primary melt composition (see above and Table S4) and these $\mathrm{CO}_{2} / \mathrm{Nb}$ ratios, the primary $\mathrm{CO}_{2}$ content of the Holuhraun melt is estimated to be between 850 and 1370 ppm (Table 1).

$\mathrm{H}_{2} \mathrm{O}$ :

We observe no systematic correlation between $\mathrm{H}_{2} \mathrm{O}$ and other major or trace elements in the melt inclusions (Fig. 5a, b and c). One possibility to account for this lack of correlation is the post-entrapment modification of melt inclusion $\mathrm{H}_{2} \mathrm{O}$ contents by $\mathrm{H}^{+}$diffusion when melt inclusions re-equilibrate with their external environment (Danyushevsky et al. 2002, Hartley et al. 2015). Unmodified $\mathrm{H}_{2} \mathrm{O}$ contents can be estimated using $\mathrm{Ce}$ as a proxy for the initial $\mathrm{H}_{2} \mathrm{O}$ content if $\mathrm{H}_{2} \mathrm{O} / \mathrm{Ce}$ for the primary melt is known. The Ce contents of Holuhraun groundmass glasses follow a tight compositional trend (Fig. 3), in contrast with $\mathrm{H}_{2} \mathrm{O}$. A group of evolved groundmass glass compositions have less than $0.2 \mathrm{wt} \% \mathrm{H}_{2} \mathrm{O}$ (Fig. 5). These groundmass glasses were highly vesicular and they are considered to be degassed. $\mathrm{H}_{2} \mathrm{O}$ in the non-vesicular groundmass glasses is positively correlated with $\mathrm{K}_{2} \mathrm{O}$ and $\mathrm{Ce}$ and negatively correlated with $\mathrm{MgO}$, as expected during fractional crystallisation. These glass compositions 
have an average $\mathrm{H}_{2} \mathrm{O} / \mathrm{Ce}$ ratio of $253 \pm 64(1 \sigma)$. This ratio is slightly higher than that estimated

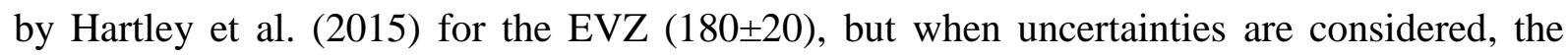
ratios overlap and fall within the range estimated for MORBs (150-280; Michael, 1995). These ratios are also similar to those observed in submarine basaltic glasses and olivinehosted melt inclusions in tephra samples from the Azores (Dixon et al., 2002 and Métrich et al. 2014). Many melt inclusions have $\mathrm{H}_{2} \mathrm{O} / \mathrm{Ce}>>253$, indicative of diffusive over-hydration during the storage of these inclusions in a more hydrous carrier melt (Hartley et al. this issue), whereas those with $\mathrm{H}_{2} \mathrm{O} / \mathrm{Ce}<<253$ have lost $\mathrm{H}^{+}$by diffusive dehydration.

Using the calculated Ce contents in the most primitive melt inclusions and assuming an undegassed $\mathrm{H}_{2} \mathrm{O} / \mathrm{Ce}$ ratio of 253 for the Holuhraun magma, the $\mathrm{H}_{2} \mathrm{O}$ content in the Holuhraun parental melt is estimated to be between 0.12 and 0.17 wt.\% (Fig. 5a, b). None of the primitive melt inclusions show such low $\mathrm{H}_{2} \mathrm{O}$ contents, which is consistent with the suggestion that these primitive inclusions gained $\mathrm{H}_{2} \mathrm{O}$ via diffusive re-equilibration with a more hydrous carrier liquid prior to eruption. In contrast, on the basis of the mean Ce content of the evolved melt inclusions and matrix glasses $(21.5 \mathrm{ppm})$, we estimate the undegassed $\mathrm{H}_{2} \mathrm{O}$ content of the Holuhraun carrier liquid to be 0.61 wt.\%. This concentration is in good agreement with $\mathrm{H}_{2} \mathrm{O}$ contents predicted by fractional crystallisation from a parental melt with $0.15 \mathrm{wt} \% \mathrm{H}_{2} \mathrm{O}$ using the mineral-melt models of Danyushevsky (2001) (Supplementary Material, S4). It is therefore possible that the two groundmass glass analyses with $\mathrm{H}_{2} \mathrm{O}>0.8$ wt.\% (Fig. 5), which were obtained adjacent to a large plagioclase macrocryst, represent an incompatible element-enriched boundary layer surrounding the crystal.

Based on the established $\mathrm{H}_{2} \mathrm{O} / \mathrm{Ce}$ ratio of $253 \pm 64$ and the primary $\mathrm{Ce}$ content calculated for the Holuhraun magma (Table S4), we estimate that the primary $\mathrm{H}_{2} \mathrm{O}$ content to be $0.15 \pm 0.03$ wt.\% (Table 1). Similar $\mathrm{H}_{2} \mathrm{O}$ contents were reconstructed in primitive olivine hosted melt inclusions from Equatorial Mid-Atlantic Ridge by Le Voyer et al. (2017). 


\section{Chlorine:}

The variability in $\mathrm{Cl}$ contents cannot be explained by fractional crystallisation alone, since $\mathrm{Cl}$ is expected to behave as an incompatible trace element in a $\mathrm{Cl}$-undersaturated melt. Given that $\mathrm{Cl}^{-}$solubility in $\mathrm{H}_{2} \mathrm{O}$-poor basaltic melts is on a wt.\% level, even at atmospheric pressure (e.g. Webster et al. 1999), $\mathrm{Cl}$ is not expected to degas. The apparent decrease in mean melt inclusion $\mathrm{Cl}$ content with decreasing $\mathrm{MgO}$ may therefore be the result of mixing between $\mathrm{Cl}$-rich (similar to E-MORB) and $\mathrm{Cl}$-poor (similar to $\mathrm{N}-\mathrm{MORB}$ ) melts in the Holuhraun magmatic system (Fig. 6a, b).

Although melt inclusion $\mathrm{Cl}$ concentrations are widely scattered, due partially to analytical uncertainty, melt inclusion $\mathrm{Cl} / \mathrm{K}$ ratios typically fall between 0.01 and 0.08 , and are similar to N-MORB and E-MORB glasses (Michael and Cornell, 1998) (Fig. 6a and 6b). However, three of the most primitive melt inclusions have $\mathrm{Cl} / \mathrm{K}$ higher than typical MORB values (Fig. 6b). Previous studies on oceanic basalts have explained elevated $\mathrm{Cl} / \mathrm{K}$ as a result of interaction with seawater or brine (Kent et al. 1999), or assimilation of hydrothermally altered crustal material (Saal et al. 2002). The Holuhraun vents are located $>100 \mathrm{~km}$ from the nearest coastline so seawater contamination can be excluded. Indeed, a recent study by Halldórsson et al. (2016) highlights the limited role of seawater-derived enrichments in chlorine systematics of Icelandic basalts.

Note that the $\mathrm{Cl}$ contents of the most primitive melt inclusions cover a narrow range (47-71 ppm) within analytical error (Fig. 6a). Thus, the variability of $\mathrm{Cl} / \mathrm{K}$ ratios is the result of the two- to three-fold variation in $\mathrm{K}_{2} \mathrm{O}$ contents instead of the variation of $\mathrm{Cl}$ concentrations (Table S2). Moreover, there is a weak negative correlation $\left(r^{2}=0.55\right)$ between $\mathrm{Cl} / \mathrm{K}$ and $\mathrm{La} / \mathrm{Yb}$ (Fig. 6c) among the five most primitive melt inclusions, signifying that the K-rich melt inclusions are also somewhat more enriched in light rare earth elements (LREE) 
than the $\mathrm{K}$-poor ones. Therefore, we suggest that $\mathrm{Cl} / \mathrm{K}$ ratios in the most primitive melt inclusions denote a variation of the mantle source rather than shallow level contamination.

Our calculations suggest that the primary $\mathrm{K}$ content of the Holuhraun melt is on average $640 \mathrm{ppm}$, though this value might vary between 400 and $800 \mathrm{ppm}$, as observed in the variation among the most primitive melt inclusions (Table S2). Combining these values with the observed maximum and minimum $\mathrm{Cl} / \mathrm{K}$ ratios $(0.02-0.16)$, the primary $\mathrm{Cl}$ content of the Holuhraun magma is estimated to be between 13 and 102 ppm (Table 1).

\section{Fluorine:}

The incompatibility of $\mathrm{F}$ and $\mathrm{Nd}$ has been found to be similar during mantle melting (Workman et al. 2006). Typical mid-ocean ridge basalts have F/Nd ratios of $20.8 \pm 5.8$ (e.g. Workman et al. 2006). Groundmass glasses and melt inclusions trapped in olivine and clinopyroxene have $\mathrm{F} / \mathrm{Nd}=30 \pm 5.3$ (Table S2, Fig 7), which is slightly higher than N-MORB. In contrast, melt inclusions trapped in plagioclase have F/Nd ratios between 15 and 130, with some $85 \%$ of the inclusions having $\mathrm{F} / \mathrm{Nd}>21$ (Fig. $7 \mathrm{c}$ ). This suggests that plagioclase-hosted melt inclusions in Holuhraun generally do not preserve the $\mathrm{F} / \mathrm{Nd}$ ratios of their parental melts.

The anomalous behaviour of $\mathrm{F}$ in plagioclase-hosted melt inclusions might be the result of two complementary processes.

The observed $\mathrm{F}$ enrichment might reflect trapping of high- $\mathrm{Al} /(\mathrm{Al}+\mathrm{Si})$ boundary layers along plagioclase, into which $\mathrm{F}$ diffused due to the high solubility of $\mathrm{F}$ in Al-rich silicate melts. This mechanism has been proposed to explain elevated $\mathrm{F} / \mathrm{Nd}$ in plagioclase-hosted melt inclusions from the $10 \mathrm{ka}$ Grimsvötn tephra series (Neave et al. 2017). In this case, the trapped melt inclusions have anomalously high Al contents which may later disappear by extensive PEC and re-equilibration of $\mathrm{Al}$ and $\mathrm{Si}$ between the melt inclusion and its host plagioclase. If this is the case, we should observe a correlation between PEC and F excesses (Fig. S5). We observe a weak positive correlation between PEC and F/Nd ratios $\left(\mathrm{r}^{2}=0.46\right)$, 
with the most primitive melt inclusions that needed PEC correction above $15 \%$ having the highest F/Nd. But F excess in melt inclusions that experienced smaller degrees of PEC (3$10 \%)$ is still significant.

A second process might be the diffusive re-equilibration of melt inclusions with F-rich carrier liquid. Fast equilibration of olivine-hosted melt inclusions with F-rich carrier melt has been observed during high-T experiments (Portnyagin et al. 2008). Fluorine diffusion rates in plagioclase have not been quantified and this process cannot therefore be quantitatively modelled. However, we note that for the majority of plagioclase-hosted melt inclusions from the first 10 days of the eruption, $\mathrm{F}$ is negatively correlated with $\mathrm{MgO}$ (Fig. 7a). Their compositions can be modelled with the same F-Nd-MgO systematics as the undegassed groundmass glasses and melt inclusions trapped in the other mineral phases. This correlation disappears among the melt inclusions collected later.

These observations suggest that the variation of $\mathrm{F} / \mathrm{Nd}$ ratios in plagioclase-hosted melt inclusions might be biased by two processes. Therefore, they are not good candidates to estimate the F contents of parental melts or the F content of the Holuhraun mantle source. On the other hand, the fractional crystallisation relationship for all undegassed groundmass glasses, as well as clinopyroxene- and olivine-hosted melt inclusions, can be reproduced by two trends which are superimposed on Figure 7. These were calculated based on Nd variation along a liquid line of descent from the most primitive melt inclusions assuming $\mathrm{F} / \mathrm{Nd}=25$ (gray dashed arrow) and $\mathrm{F} / \mathrm{Nd}=45$ (black arrow) (Fig. 6b). This enables us to estimate $\mathrm{F}$ contents in the Holuhraun primary melt to be between 130-230 ppm (Fig. 6b, Table 1).

\section{Sulphur:}

The S/Dy ratio is expected to remain unmodified during fractional crystallisation of a sulphur-undersaturated melt (e.g.: Saal et al. 2002). Typical N-MORB basalts have S/Dy 
between 150 and 300 (Shimizu et al. 2016). However, Holuhraun melt inclusions have S/Dy ratios of 200-600, and therefore show a larger variation than is expected for basalt derived from a single N-MORB source (Fig. 8b). The variability in S/Dy is greatest in the most primitive melt inclusions ( 280 to $\sim 600$ ), but generally decreases with decreasing $\mathrm{MgO}$ (Figure 8b). Nevertheless, a significant portion of moderately evolved melt inclusions have $\mathrm{S} / \mathrm{Dy}$ ratios above MORB values. Some of the most evolved melt inclusions (with $\mathrm{Mg} \#$ of 45) and glasses have low S/Dy values, but these melts have likely been affected by degassing, as can be inferred from Figure 8a.

The majority of the scatter observed in S/Dy ratios among the moderately evolved to most primitive melt inclusions is in fact caused by the scatter in Dy concentrations (Fig. 3), whereas $\mathrm{S}$ contents in the same melt inclusions cover a relatively narrow range (Fig. 8a). Among the most primitive melt inclusions this is due to high analytical uncertainty at low Dy contents. Omitting these melt inclusions and those that are degassed, S/Dy ratios in the melt inclusions range between 350 and 220. The systematics of S-Dy-MgO in all non-degassed melt inclusions can be reproduced based on these S/Dy ratios (Fig. 8a) if the parental Dy concentration is assumed to be $\sim 2.5 \mathrm{ppm}$, instead of 1.8. Although the average Dy content of the most primitive melt inclusions is $1.8 \mathrm{ppm}$, the assumed $2.5 \mathrm{ppm}$ Dy as parental Dy concentration (Supplementary material) is within analytical uncertainty (Fig. 3d). Based on the estimated primary Dy content and the established S/Dy ratios, we suggest $\mathrm{S}$ contents of 250 to $820 \mathrm{ppm}$ in the Holuhraun primary melt (Table 1).

On the basis of the relationships between major, trace and volatile elements described in the previous paragraphs, we conclude that the variations in volatile contents are the result of magma mixing and fractional crystallisation. This is in accordance with the variation of incompatible trace elements in the same set of melt inclusions described in details by Hartley 
et al. (this volume). During this process, a pre-existing crystal mush could have also been remobilised by the carrier liquid. The remobilisation of crystal mush can also explain the presence of secondary and pseudosecondary melt and fluid inclusions in the macrocrysts, which are not expected to be produced during a crystallization process in the conduit.

\section{Estimation of volatile contents in the Holuhraun mantle source(s)}

In order to calculate the mantle source compositions, we assume that a $\mathrm{Na}_{2} \mathrm{O}$ content of 1.62 wt.\% (Table S3) is representative for the primary melt of the Holuhraun magma. We also assume that the mantle source is dominated by depleted mantle that contains 0.28 wt.\% $\mathrm{Na}_{2} \mathrm{O}$ (Workman and Hart 2005). Using the Na partition coefficients of $\mathrm{D}_{0}=0.03$, suggested by Langmuir et al. (1992), and reorganising the non-modal batch melting equation, we calculate that the Holuhraun parental melt is the result of $15 \%$ partial melting of a depleted MORB mantle.

The volatile contents of the mantle source were calculated assuming the previously calculated primary volatile contents; $15 \%$ partial melting; and non-modal batch partial melting process to be representative. Table 1 contains the bulk partition coefficients applied for each volatile element. We calculate 128 to $206 \mathrm{ppm}$ of $\mathrm{CO}_{2}$ (Table 1) in the mantle source of the Holuhraun magma. These estimates are higher than the Depleted MORB Mantle

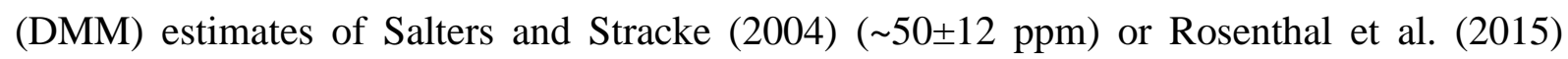
(75 $\pm 25 \mathrm{ppm})$, but are similar to the estimates of Le Voyer et al (2017) (137 \pm 54$)$. The estimated $\mathrm{H}_{2} \mathrm{O}$ content of the mantle source is between 190 and 260 ppm (Table 1), which is also slightly higher than has been suggested for DMM (116 \pm 58 ppm - Salters and Stracke,

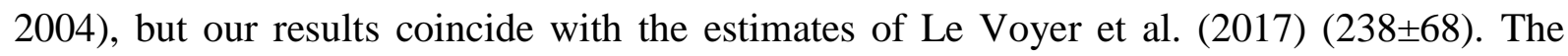
estimated $\mathrm{Cl}$ content of the Holuhraun mantle source is between 3 and $15 \mathrm{ppm} \mathrm{Cl}$ (Table 1). This large range of $\mathrm{Cl}$ contents is in accordance with the results of Halldórsson et al. (2016) 
who suggested that the mantle source beneath Iceland is heterogeneous in halogens based on $\mathrm{Cl}$ isotope variation. These values are an order of magnitude higher than concentrations proposed for the DMM $(0.51 \pm 0.09 \mathrm{ppm}$ - Salters and Stracke, 2004; 0.14-0.38 ppm - Urann et al., 2017). The lower concentrations are, on the other hand, close to the MORB source estimates of Le Voyer et al (2017) (4.1 \pm 1.2$)$ whereas the higher estimates are in the range estimated for the enriched MORB source by Shimizu et al. (2016) (22 ppm). The F content of the mantle source is estimated to be in the range of 20 to $40 \mathrm{ppm}$. The lower estimate is close

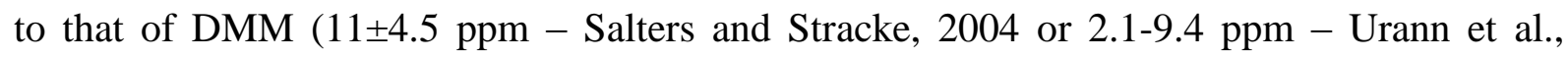
2017), whereas the higher estimate is consistent with the presence of a mantle source which is somewhat more enriched in F than DMM (E-DMM: $31 \mathrm{ppm}$, Shimizu et al., 2016). The S content of the mantle source is difficult to deduce since the Dy content of the primary melt and the primary Dy/S ratio are uncertain. The estimated range is between 50 and $200 \mathrm{ppm} \mathrm{S}$ (Table 1), most probably between $100-160$ ppm S (Table 2). This estimate is again similar to DMM (119 \pm 30 ppm - Salters and Stracke, 2004, 100-165, Shimizu et al., 2016).

\section{Degassing history}

$\mathrm{CO}_{2}$

The complex interplay between fluid saturation, pre-eruptive deep and syn-eruptive degassing, as well as post-entrapment modification of melt inclusion $\mathrm{CO}_{2}$ contents (e.g. through decrepitation) makes it difficult to determine the total $\mathrm{CO}_{2}$ release associated with ascent and eruption of the Holuhraun magma with petrologic methods. $\mathrm{CO}_{2}$ release might have occurred in a number of steps during magma evolution. $\mathrm{CO}_{2}$ could have been released from a deep magma reservoir(s) well before the volcanic eruption and the product of this process could be traced in geothermal water around the area (e.g.: Barry et al., 2014). Syneruptive $\mathrm{CO}_{2}$ degassing is associated with magma transfer from 8-12 km (Gudmundsson et 
al., 2016, Hartley et al., and Halldórsson et al., both this issue) to the dyke and from the dyke to the surface. Here we separate these processes, first estimating the total $\mathrm{CO}_{2}$ budget and compare it to the syn-eruptive $\mathrm{CO}_{2}$ release.

The total $\mathrm{CO}_{2}$ budget of the eruption was calculated as described by Hartley et al. (2014). In this method, a trace element proxy such as $\mathrm{Nb}$ or $\mathrm{Ba}$ is used to estimate total $\mathrm{CO}_{2}$ degassed prior to trapping of each melt inclusion, and the cumulative total $\mathrm{CO}_{2}$ loss is then calculated by associating each melt inclusion with a mass of melt. An advantage of this method is that it is possible to reconstruct the likely path of $\mathrm{CO}_{2}$ loss as a function of pressure and extent of crystallisation. The principal uncertainty lies in the $\mathrm{CO}_{2} / \mathrm{Nb}$ or $\mathrm{CO}_{2} / \mathrm{Ba}$ ratio assumed to be representative of the undegassed primary melt. Rosenthal et al. (2015) showed that the partition coefficient of $\mathrm{CO}_{2}$ lies between those of $\mathrm{Nb}$ and $\mathrm{Ba}$ during partial melting and fractional crystallisation. We therefore assumed a primary $\mathrm{CO}_{2} / \mathrm{Nb}$ of 314 (Hauri et al., 2002) to calculate a minimum estimate of the $\mathrm{CO}_{2}$ mass release from the Holuhraun magma, and a primary $\mathrm{CO}_{2} / \mathrm{Ba}$ of 110 (Michael and Graham, 2015) to calculate a maximum estimate of the total $\mathrm{CO}_{2}$ mass release. We assume no systematic variation in $\mathrm{CO}_{2} / \mathrm{Nb}$ and $\mathrm{CO}_{2} / \mathrm{Ba}$ between enriched and depleted primary melt compositions and our calculations do consequently not take into account magma mixing within the Holuhraun magmatic plumbing system.

Total $\mathrm{CO}_{2}$ mass release from the Holuhraun magma was calculated for all melt inclusions with measured $\mathrm{CO}_{2}$ contents $(\mathrm{n}=84)$, as well as by using a subset of 63 melt inclusions for which reliable melt equilibration pressures can be calculated with OPAM barometry (Hartley et al. this issue). The results of our calculations are summarised in Figure 10a and $\mathrm{b}$. The total $\mathrm{CO}_{2}$ mass release calculated is at least $23 \mathrm{Mt}$ using $\mathrm{Nb}$ as a proxy for undegassed $\mathrm{CO}_{2}$, or $55 \mathrm{Mt}$ using $\mathrm{Ba}$ as a proxy for undegassed $\mathrm{CO}_{2}$. The true total $\mathrm{CO}_{2}$ mass release is likely to lie between these extremes. 
Thermobarometric and geodetic studies indicate that the Holuhraun magma was drained from a magma reservoir evolving at 0.25-0.3 GPa pressure. The presence of highdensity fluid inclusions (Table 1) suggests that at this depth the magma was saturated in $\mathrm{CO}_{2}$. Before the eruption the magma was first emplaced as a shallow dyke at 5-7 km depth and then erupted at the surface. Syn-eruptive $\mathrm{CO}_{2}$ release can be estimated based on the difference in $\mathrm{CO}_{2}$ contents between the $\mathrm{CO}_{2}$-saturated magma composition at $0.25-0.3 \mathrm{GPa}$ pressure and under atmospheric conditions $\left(\Delta \mathrm{CO}_{2}\right)$, multiplied by the total mass of degassing magma (see mass conversation equations for magma degassing in, e.g., Thordarsson et al., 2001). There is some uncertainty in estimates of $\mathrm{CO}_{2}$ solubility in basaltic melts at $0.25-0.3 \mathrm{GPa}$, therefore we calculate two endmember scenarios using the solubility model of Shishkina et al. (2014) to obtain a maximum value, and the VolatileCalc model of Newman and Lowenstern (2002) to obtain a minimum value. The model of Shishkina et al. (2014) predicts that, at 0.25-0.3 GPa, the Holuhraun melt could have contained $2200 \pm 300 \mathrm{ppm} \mathrm{CO}_{2}$, whereas the VolatileCalc model predicts only $1400 \pm 200 \mathrm{ppm} \mathrm{CO}_{2}$ in the same melts. The vesicular groundmass glasses, representing the degassed magma, contain $\mathrm{CO}_{2}$ below the 20 ppm detection limit of the SIMS analyses. The total mass of the erupted magma has been estimated to be $4.2 \pm 0.8 \times 10^{12} \mathrm{~kg}$ (Gíslason et al., 2015). According to Sigmundsson et al. (2015), $0.49 \pm 0.02 \mathrm{~km}^{3}$ of magma was stored in the dyke. Applying the same magma density $\left(2.6 \mathrm{~g} / \mathrm{cm}^{3}\right)$ as assumed by Gíslason et al. (2015), this volume corresponds to a mass of $1.3 \times 10^{12} \mathrm{~kg}$. Therefore, the total mass of magma drained from the deep magma storage towards the surface is approximately $5.5 \pm 0.8 \times 10^{12} \mathrm{~kg}$. The syn-eruptive $\mathrm{CO}_{2}$ release can thus be calculated as:

$$
\Delta \mathrm{CO}_{2}=\left(\mathrm{CO}_{2} \text { at } 0.25-0.3 \mathrm{GPa}-\mathrm{CO}_{2} \text { at } 1 \mathrm{~atm}\right)(1)
$$

$$
\mathrm{CO}_{2} \text { released }=\Delta \mathrm{CO}_{2} * \text { total degassed magma mass (2) }
$$


Consequently, we estimate a syn-eruptive $\mathrm{CO}_{2}$ degassing of 7.2-5.9 Mt (Table 2). This result is in excellent agreement with the results of combined in situ DOAS and MultiGAS measurements yielding a syn-eruptive $\mathrm{CO}_{2}$ release of 5.6+/-3.8 Mt (Gíslason et al. 2015), and open-path FTIR and UV spectroscopy indicate total $\mathrm{CO}_{2}$ emissions of $\sim 5.36 \mathrm{Mt}$ (Burton et al., submitted).

Combining our results with the estimates of effusion rate (Bony et al., 2017) we calculated the variation of $\mathrm{CO}_{2}$ flux during the eruption (Fig. 10c). The highest calculated $\mathrm{CO}_{2}$ flux was as much as $\sim 150 \mathrm{kt} /$ day in early September which decreased to $20-30 \mathrm{kt} /$ day towards the end of the eruption. These estimates are in a good agreement with those determined by Gíslason et al. (2015) based on field measurements in two different periods of the eruption (Fig. 10c). The calculated average $\mathrm{CO}_{2}$ flux for the Holuhraun eruption is at least double the estimated passive $\mathrm{CO}_{2}$ flux in Iceland (Barry et al. 2014), but approximately 30 times lower than that estimated for the 1783-84 Laki eruption (Hartley et al. 2014) (Table 2). It must, however, be noted that the Laki estimates include the deep degassing component too, which is omitted during our calculations.

\section{$\mathrm{H}_{2} \mathrm{O}$}

The undegassed $\mathrm{H}_{2} \mathrm{O}$ content of the Holuhraun carrier liquid could have reached 0.4$0.6 \mathrm{wt} \%$ through fractional crystallisation alone (Fig. 5). This is in agreement with the highest $\mathrm{H}_{2} \mathrm{O}$ contents observed in the melt inclusions. Although many of the Holuhraun melt inclusions do not appear to preserve their original $\mathrm{H}_{2} \mathrm{O}$ contents, syn-eruptive water release during the eruption can nonetheless be estimated from the difference between the most $\mathrm{H}_{2} \mathrm{O}-$ rich melt inclusions $\left(0.59\right.$ wt.\% $\left.\mathrm{H}_{2} \mathrm{O}\right)$ and the degassed carrier liquid $\left(0.06\right.$ wt.\% $\left.\mathrm{H}_{2} \mathrm{O}\right)$ multiplied by the total mass of magma at $\mathrm{H}_{2} \mathrm{O}$ saturation. The total mass of magma at $\mathrm{H}_{2} \mathrm{O}$ saturation here is essentially equal to the total mass of the erupted magma $\left(4.2 \pm 0.8 \times 10^{12} \mathrm{~kg}\right.$ 
(Gíslason et al. 2015) as $\mathrm{H}_{2} \mathrm{O}$ release is only expected near the surface. Based on this, we calculate a total syn-eruptive $\mathrm{H}_{2} \mathrm{O}$ emission of $22.2 \mathrm{Mt}$. This is only $8-40 \%$ of the total $\mathrm{H}_{2} \mathrm{O}$ release measured in the field (Gíslason et al. 2015, Burton et al., submitted), suggesting a significant incorporation of meteoric water to the results of direct field measurements (Table 2). The $\mathrm{H}_{2} \mathrm{O}$ flux reached $350-400 \mathrm{kt} /$ day in September and decreased to $100 \mathrm{kt} /$ day in the last 2 months of the eruption (Fig. 10c).

\section{Sulphur}

The detection of $\mathrm{SO}_{2}$ in a fluid inclusion with density of $0.26 \mathrm{~g} / \mathrm{cm}^{3}$ indicates that $\mathrm{SO}_{2}$ degassing from the Holuhraun magma commenced at pressures $\geq 0.12 \mathrm{GPa}$, corresponding to $\geq 3.7 \mathrm{~km}$ depth (Fig. 8). Measured S contents in moderately to highly evolved melt inclusions are very close to, or above, those predicted by the S saturation model of Ariskin et al. (2013) at $0.12 \mathrm{GPa}$ and $f \mathrm{O}_{2}$ of FMQ+0.5 (Fig. 7a, details of modelling in Supplementary material). This suggests that $\mathrm{S}$ saturation under these conditions is plausible. Based on this model $\sim 88 \%$ of sulphur in the studied melt compositions dissolved as $\mathrm{S}^{2-}$ at FMQ+0.5. Therefore, sulphide globules, such as those observed in Holuhraun tephras, are expected to form once sulphide saturation is reached. Sulphide inclusions are present in microphenocrysts (Fig. 2g), confirming that sulphide saturation was indeed reached before the magma reached the surface. However, $\mathrm{S}^{6+}$ is also present in the melt, which, upon sulphur saturation, is degassed as $\mathrm{SO}_{2}$ and trapped in fluid inclusions alongside the $\mathrm{CO}_{2}$-rich fluid phase.

The highest $\mathrm{S}$ concentration in the evolved melt inclusions was $1700 \mathrm{ppm}$, likely representing the undegassed carrier liquid close to sulphide saturation. The most degassed glass contained $350 \mathrm{ppm} \mathrm{S}$. This difference multiplied by the total erupted magma mass suggests a total $\mathrm{SO}_{2}$ release of $10.5 \mathrm{Mt}$ during the Holuhraun eruption (Table 2). $\mathrm{SO}_{2}$ emissions can also be estimated using the empirical model of Thordarson et al. (2003), which depends on the general relationship between undegassed and degassed $\mathrm{S}$ contents of basaltic 
melts at a given $\mathrm{Ti} / \mathrm{Fe}$ ratio. Using this method, we calculate a total $\mathrm{SO}_{2}$ release of $8.6 \mathrm{Mt}$ from the Holuhraun eruption. This estimate is similar to that of Gíslason et al. (2015) who derived the sulphur emission from the relationship between the Fe content of sulphursaturated tholeiitic basalts and sulphur yield (Blake et al. 2010). From field measurements, the total $\mathrm{SO}_{2}$ release is estimated to be $\sim 11.8 \mathrm{Mt}$ (Gíslason et al. 2015), which is in good agreement with that predicted by either of the petrologic methods.

The average daily $\mathrm{S}$ flux during this eruption is an order of magnitude lower than that estimated for the 1783-84 Laki eruption, but comparable to that estimated for the 934-940 AD Eldgjá eruption (Thordarson et al. 2001) (Table 2). The highest sulphur flux in September might have reached as high as 150-200 kt/day, which is in good agreement with the field measurements in that period (Gíslason et al. 2015). In the last two month of the eruption, this flux decreased to $\sim 50 \mathrm{kt} /$ day.

\section{Fluorine and chlorine}

Fluorine and chlorine concentrations in the melt inclusions are statistically indistinguishable from those in the matrix glasses, suggesting minimal $\mathrm{F}$ and $\mathrm{Cl}$ degassing during ascent and eruption. This is consistent with solubility models, which indicate $\mathrm{F}$ and $\mathrm{Cl}$ solubilities of several wt.\% in $\mathrm{H}_{2} \mathrm{O}$-poor basalts (Webster et al. 1999; Tollari et al. 2008). Concentrations of $\mathrm{F}$ and $\mathrm{Cl}$ in snow melt from nearby Dyngjujökull glacier showed positive correlations with $\mathrm{SO}_{4}{ }^{2-}$ (Gíslason et al. 2015), indicating at least some $\mathrm{F}$ and $\mathrm{Cl}$ outgassing from the Holuhraun magma. However, the lack of difference between melt inclusion and matrix glass halogen concentrations suggests that syn-eruptive degassing budgets for $\mathrm{F}$ and $\mathrm{Cl}$ from the Holuhraun magma cannot be accurately constrained by petrological methods.

\section{CONCLUSIONS}


We have presented an in-depth study of volatile systematics of the 2014-2015 Holuhraun magma, constrained by detailed geochemcial data from crystal-hosted melt and fluid inclusions. Our major conclusions are as follows:

1) Fluid inclusion thermobarometry demonstrates that some macrocrysts in the Holuhraun magma were carried to the surface from depths in excess of $12 \mathrm{~km}$.

2) $\mathrm{CO}_{2}$ contents of most melt inclusions have been modified by post-entrapment processes during their transport to the surface.

3) The volatile content of the primary melt is estimated at $850-1370 \mathrm{ppm} \mathrm{CO}_{2}, 0.12-$ 0.17 wt. $\% \mathrm{H}_{2} \mathrm{O}, 10-100$ ppm Cl, 130-230 ppm F and 530-840 ppm S.

4) These estimates correspond to mantle source contents of $130-200 \mathrm{ppm} \mathrm{CO}_{2}, 190$ 260 ppm $\mathrm{H}_{2} \mathrm{O}, 3-15$ ppm Cl, 20-40 ppm F and 50-200 ppm S, which are generally in good agreement with estimates for DMM, although halogens suggest some source heterogeneity.

5) Sulphur saturation was achieved at $\geq 3.6 \mathrm{~km}$ depth, resulting in both $\mathrm{SO}_{2}$ fluid and immiscible sulphide melt. Sulphur solubility in melt inclusions suggests oxidising conditions (FMQ+0.5) during magma ascent.

6) Petrologic estimates of syn-eruptive $\mathrm{CO}_{2}$ and $\mathrm{SO}_{2}$ release for the Holuhraun eruption (5.9-7.2 and 10.5 Mt, respectively) are in good agreement with those observed by in situ field measurements. The estimated $\mathrm{H}_{2} \mathrm{O}$ release is, however, significantly lower than indicated by the field measurements. Halogen release into the eruption plume was insignificant, and a precise halogen budget cannot be accurately constrained by the petrological method adopted here.

The close match between the volatile release estimates for most volcanic gases based on melt inclusions and in situ measurements of the plume chemistry demonstrates the validity of melt inclusion studies in reconstructing pre- and syn-eruptive volatile budgets of historic 
and prehistoric eruptions. On the other hand, the discrepancy between the measured and calculated $\mathrm{H}_{2} \mathrm{O}$ release shows that petrologic estimates are essential for the precise interpretation of field data.

\section{References:}

Ariskin AA Dayushevsky LV, Bychkov KA, McNeill AW, Barmina GS, Nikolaev GS (2013) Modeling solubility of Fe-Ni sulfides in basaltic magmas: The effect of Nickel. Economic Geology, 108, 1983-2003.

Baasner A, Schmidt BC, Webb SL (2013) The effect of chlorine, fluorine and water on the viscosity of aluminosilicate melts. Chemical Geology, 357, 134-149.

Baker DR (2008) The fidelity of melt inclusions as records of melt composition. Contributions to Mineralogy and Petrology, 156, 377-395

Barry PH, Hilton DR, Furi E, Halldórsson SA, Grönvold K. (2014) Carbon isotope and abundance systematics of Icelandic geothermal gases, fluids and subglacial basalts with implications for mantle plume-related $\mathrm{CO} 2$ fluxes. Geochimica et Cosmochimica Acta, 134, 74-99.

Berkesi M, Hidas K, Guzmics T, Dubessy J, Bodnar RJ, Szabo Cs, Vajna B, Tsunogae T (2009) Detection of small amounts of H2O in CO2-rich fluid inclusions using Raman spectroscopy. Journal of Raman Spectroscopy, 40, 1461-1463.

Black BA, Elkins-Tanton LT, Rowe MC, Peate IU (2012) Magnitude and consequences of volatile release from the Siberian Traps. Earth and Planetary Science Letters, 317-318, 363-373.

Blake S, Self S, Sharma K, Sephton S (2010) Sulfur release from the Columbia River Basalt and other flood lava eruptions constrained by a model of sulfide saturation. Earth and Planetary Science Letters, 299, 328-338. 
Bony E, Thordarson T, Wright R, Höskuldsson A, Jónsdóttir I (2017) The magma discharge and the volume of lava erupted during the 2014-2015 eruption on Dyngjusandur, North Iceland as determined by ground based and satellite derived measurements. Vorráðstefna Jarðfræðafélags Islands Abstract book, p 14-15.

Breddam K (2002) Kistufell: primitive melt from the Iceland mantle plume. J Petrol 43:345373.

Burton M, Ilyinskaya E, Hartley ME, La Spina A, Salerno G, Bali E, Barsotti S, Bergsson B, Pfeffer MA, Kaasalainen H, Stefansson A, Thordarson T: Mantle source controls gas emissions and impact of Icelandic basaltic eruptions. Submitted to Nature Geoscience.

Condomines M, Grönvold K, Hooker PJ, Muehlenbachs K, O’Nions RK, Oskarsson N, Oxburgh ER (1983) Helium, oxygen, strontium and neodymium isotopic relationships in Icelandic volcanics. Earth Planet Sci Lett 66:125-136.

Dalou C, Koga KT, Shimizu N (2009) Chlorine and Fluorine partitioning between peridotite and basalt at mantle wedge conditions: Implications for arc magma source. AGU Abstract.

Dixon JE, Stolper EM, Holloway JR (1995) An experimental study of water and carbon dioxide solubilities in mid ocean ridge basaltic liquids .1. Calibration and solubility models. Journal of Petrology, 36, 1607-1631.

Dixon JE, Leist L, Langmuir C, Schilling JG (2002). Recycled dehydrated lithosphere observed in plumes influence mid-ocean ridge basalt. Nature 420(28), 385-389.

Danyushevsky LV (2001) The effect of small amounts of $\mathrm{H} 2 \mathrm{O}$ on crystallisation of mid-ocean ridge and backarc basin magmas. Journal of Volcanology and Geothermal Research, 34, 265-280. 
Danyushevsky LV, McNeill AW, Sobolev AV (2002): Experimental and petrological studies of melt inclusions in phenocrysts from mantle-derived magmas: an overvi.ew of techniques, advantages and complications. Chem. Geol., 183, 5-24

Danyushevsky LV, Plechov P (2011) Petrolog3: Integrated software for modeling crystallization processes, Geochemistry Geophysics Geosystems, 12, Q07021.

Esposito R, Lamadrid HM, Redi D, Steele-McInnis M, Bodnar RJ, Manning CE, DeVivo B, Cannatelli C, Lima A (2016) Detection of liquid H2O in vapor bubbles in reheated melt inclusions: Implications for magmatic fluid composition and volatile budgets of magmas? American Mineralogist, 101, 1691-1695.

Fall A, Tattich B, Bodnar RJ (2011): Combined microthermometric and Raman spectroscopic technique to determine the salinity of $\mathrm{H} 2 \mathrm{O}-\mathrm{CO} 2-\mathrm{NaCl}$ fluid inclusions based on clathrate melting. Geochimica et Cosmochimica Acta, 75, 951-964.

Faure F, Schiano P. (2005) Experimental investigation of equilibration conditions during forsterite growth and melt inclusion formation. Earth and Planetary Science Letters, $236,882-898$

Frezzotti ML, Peccerillo A (2007) Diamond-bearing COHS fluids in the mantle beneath Hawaii. Earth and Planetary Science Letters, 262, 273-283.

Frezzotti ML, Tecce F, Casagli A (2012) Raman spectroscopy for fluid inclusion analysis. Journal of Geochemical Exploration, 112, 1-20.

Gauthier P-J, Sigmarsson O, Gouhier M, Haddadi B, Moune S. (2016) Elevated gas flux and trace metal degassing from the 2014-2015 fissure eruption at the Bárðarbunga volcanic system, Iceland. Journal of Geophysical Research, Solid Earth, 121, 1610-1630.

Giordano D, Russell JK, Dingwell DB (2008) Viscosity of magmatic liquids: A model. Earth and Planetary Science Letters, 271, 123-134 
Gíslason SR, Stefánsdóttir G, Pfeffer MA, Barsotti S, Jóhannsson Th, Galeczka I, Bali E, Sigmarsson O, Stefánsson A, Keller NS, Sigurdsson Á, Bergsson B, Galle B, Jacobo VC, Arellano S, Aiuppa A, Jónasdóttir EB, Eiríksdóttir ES, Jakobsson S, Guðfinnsson GH, Halldórsson SA, Gunnarsson H, Haddadi B, Jónsdóttir I, Thordarson Th, Riishuus M, Högnadóttir Th, Dürig T, Pedersen GBM, Höskuldsson Á, Gudmundsson MT (2015) Environmental pressure from the 2014-15 eruption of Bárðarbunga volcano, Iceland. Geochemical Perspectives Letters, 1, 84-93.

Gudmundsson MT, Jónsdóttir K, Hooper A, Holohan EP, Halldórsson SA, Ófeigsson BG, Cesca S, Vogfjörd KS, Sigmundsson F, Högnadóttir Th, Einarsson P, Sigmarsson O, Jarosch AH, Jónasson K, Magnússon E, Hreinsdóttir S, Bagnardi M, Parks MM, Hjörleifsdóttir V, Pálsson F, Walter TR, Schöpfer MPJ, Heimann S, Reynolds HI, Dumont S, Bali E, Gudfinnsson GH, Dahm T, Roberts M, Hensch M, Belart JMC, Spaans K, Jakobsson S, Gudmundsson GB, Fridriksdóttir HM, Drouin V, Dürig T, Adalgeirsdóttir G, Riishuus MS, Pedersen GBM, van Boeckel T, Oddsson B, Pfeffer MA, Barsotti S, Bergsson B, Donovan A, Burton MR, Aiuppa A, (2016) Gradual caldera collapse at Bárdarbunga volcano, Iceland, regulated by lateral magma outflow. Science, 353/6295, DOI: 10.1126/science.aaf8988.

Gurenko AA, Chaussidon M (1995) Enriched and depleted primitive melts included in olivine from Icelandic tholeiites: Origin by continuous melting of a single mantle column. Geochim Cosmochim Acta 59:2905-2917.

Halldórsson SA, Bali E, Hartley ME, Peate DW, Guðfinnsson GH, Jakobsson S, Bindeman I, Neave DA and the Holuhraun Eruption Team (this issue) Petrology and Geochemistry of the 2014-2015 Holuhraun eruption, Iceland: compositional characteristics, temporal variability and magma storage. 
Halldórsson SA, Barnes JD, Stefánsson A, Hilton DR, Hauri EH, Marschal EW (2016) Subducted lithosphere controls halogen enrichments in the Iceland mantle plume source. Geology. doi:10.1130/G37924.1

Hansteen TH (1991) Multi-stage evolution of the picritic Mælifell rocks, SW Iceland: constraints from mineralogy and inclusions of glass and fluid in olivine. Contrib Mineral Petrol 109:225-239.

Hansteen TH, Klugel A (2008) Fluid inclusion thermobarometry as tracer for magmatic processes. Reviews in Mineralogy and Geochemistry, 69, 143-177.

Hartley ME, Bali E, Halldórson SA, Maclennan J, Neave DA (this issue) Melt inclusion constraints on petrogenesis of the 2014-2015 Holuhraun eruption, Iceland.

Hartley ME, Maclennan J, Edmonds M, Thordarson T (2014) Reconstructing the deep CO2 degassing behaviour of large bassaltic fissure eruptions. Earth and Planetary Science Letters, 393, 120-131

Hartley ME, Neave DA, Maclennan J, Edmonds M, Thordarson T. (2015) Diffusive overhydration of olivine-hosted melt inclusions. Earth and Planetary Science Letters, 425, 168-178.

Hauri E, Grönvold K, Oskarsson N, McKenzie D (2002) Abundance of Carbon in the Icelandic Mantle: Constraints From Melt Inclusions. American Geophysical Union, Spring Meeting 2002, abstract \#V51D-03

Hirschmann MM, Tenner T, Abaud C, Withers AC (2009) Dehydration melting of nominally anhydrous mantle: The primacy of partitioning. Earth and Planetary Science Letters, 176/1-2, 54-68.

Hudson TS, White RS, Greenfield T, Ágústsdóttir T, Brisbourne A, Green RG (2017) Deep crustal melt plumbing under Bárðarbunga volcano, Iceland. Geophys Res Lett. 44, $8785-8794$. 
Jones MT, Jerram DA, Svensen HH, Grove C. (2016) The effects of large igneous provinces on the global carbon and sulphur cycle. Palaeogeography, Palaeoclimatology, Palaeoecology, 441, 4-21.

Kent AJR, Norman MD, Hutcheon I, Stolper EM (1999) Assimilation of seawater-derived components in an oceanic volcano: evidence from matrix glasses and glass inclusions from Loihi seamount, Hawaii. Chemical Geology, 156, 299-319.

Le Voyer M, Kelley KA, Cottrell E, Hauri EH (2017): Heterogeneity in mantle carbon content from CO2-undersaturated basalts. Nature Communications, 8, DOI: 10.1038/ncomms 14062.

Maclennan J. (2017) Bubble formation and decrepitation control the CO2 content of olivinehosted melt inclusions. Geochemistry, Geophysics, Geosystems, 18/2, 597-616.

Métrich N, Sigurdsson H, Meyer PS, Devin JD (1991) The 1783 Lakagigar eruption in Iceland: geochemistry, $\mathrm{CO}_{2}$ and Sulfur degassing. Contributions to Mineralogy and Petrology, 107, 435-447.

Métrich N, Wallace P (2008) Volatile abundances in basaltic magmas and their degassing paths tracked by melt inclusions. In: Minerals, Inclusions \& Volcanic Processes, (eds K. Putirka\& F. Tepley). Rev. Mineral. Geochem., 69, pp. 363-402.

Métrich N, Zanon V, Creon L, Hildebrand A, Moreira M, Ornelas Marquez F (2014) Is the 'Azores Hotspot' a Wetspot? Insights from the Geochemistry of Fluid and Melt Inclusions in Olivine of Pico Basalts. Journal of Petrology 55/2, 377-393

Meyer PS, Sigurdsson H, Schilling J-G (1985) Petrological and geochemical variations along Iceland's neovolcanic zones. J Geophys Res 90:10,043-10,072.

Michael P (1995) Regionally distinctive sources of depleted MORB: Evidence from trace elements and H2O. Earth and Planetary Science Letters, 131/3-4, 301-320. 
Michael PJ, Cornell WC (1998) Influence of spreading rate and magma supply on crystallization and assimilation beneath mid-ocean ridges: Evidence from chlorine and major element chemistry of mid-ocean ridge basalts. Journal of Geophysical Research, $103,18325-18356$.

Michael PJ, Graham DW (2015) The behavior and concentration of $\mathrm{CO}_{2}$ in the suboceanic mantle: Inferences from undegassed ocean ridge and ocean island basalts. Lithos, 236$237,338-351$.

Mysen BO (2012) Silicate-COH melt and fluid structure, their physicochemical properties, and partitioning of nominally refractory oxides between melts and fluids. Lithos, 148, $228-246$.

Newman S, Lowenstern JB (2002) VolatileCalc: a silicate melt-H2O-CO2 solution model written in Visual Basic for Excel. Computers and Geosciences, 28/5, 597-604.

Neave DA, Maclennan J, Thordarson Th, Hartley ME (2015) The evolution and storage of primitive melts in the Eastern Volcanic Zone of Iceland: the 10 ka Grímsvötn tephra series (i.e. the Saksunarvatn ash). Contributions to Mineralogy and Petrology 170, 1-23.

Neave DA, Hartley ME, Maclennan J, Edmonds M, Thordarson T (2017): Volatiles in high anorthite plagioclase-hosted melt inclusions: the 10 ka Grímsvötn tephra series, Iceland. Geochimica et Cosmochimica Acta. 205, 100-118.

Neave DA, Putirka KD (2017) A new clinopyroxene-liquid barometer, and implications for magma storage pressures under Icelandic rift zones. American Mineralogist 102, 777 794.

O’Neill H St C, Jenner FE. (2012) The global pattern of trace-element distributions in ocean floor basalts. Nature 491, 698-704.

Oppenheimer C (2004) Volcanic Degassing. in Holland, H.D. \& Turekian, K.K. (eds): Treatise on Geochemistry, 3, Elsevier, 123-166. 
Pedersen G, Höskuldsson A, Dürig T, Thordarson T, Jónsdóttir I, Riishuus MS, Oskarsson BV, Dumont S, Magnusson E, Gudmundsson MT, Sigmundsson F, Drouin VJPB (2017) Lava field evolution and emplacement dynamics of the 2014-2015 basaltic fissure eruption at Holuhraun, Iceland. Journal of Volcanology and Geothermal Research, 340, 155-169.

Pichavant M, Di Carlo I, Rotolo SG, Scalliet B, Burgisser A, La Galle N, Martel C (2013) Generation of $\mathrm{CO}_{2}$-rich melts during basalt magma ascent and degassing. Contributions to Mineralogy and Petrology, 166, 545-561.

Portnyagin M, Almeev R, Mateev S, Holtz F (2008) Experimental evidence for rapid water exchange between olivine and host magma. Earth and Planetary Science Letters, 272, $541-552$.

Putirka KD (2008) Thermometers and barometers for volcanic systems. Reviews in Mineralogy and Geochemistry, 69, 61-120.

Risku-Norja H (1985) Gabbro nodules from a picritic pillow basalt, Midfell, SW Iceland. Nord Volcanol Inst Prof Pap 8501.

Roedder E (1984) Fluid inclusions. Reviews in Mineralogy, 12, pp 646.

Rosenthal A, Hauri EH, Hirschmann MM (2015) Experimental determination of C, F and H partitioning between mantle minerals and carbonated basalt, $\mathrm{CO} 2 / \mathrm{Ba}$ and $\mathrm{CO} 2 / \mathrm{Nb}$ systematics of partial melting and $\mathrm{CO} 2$ contents of basaltic source regions. Earth and Planetary Science Letters, 412, 77-87.

Saal AE, Hauri EH, Langmuir CH, Perfit MR (2002) Vapour undersaturation in primitive mid-oceanic ridge basalt and the volatile content of Earth's upper mantle. Nature, 419, 451-455.

Salters VJM, Stracke A (2004) Composition of the depleted mantle. Geochemistry Geophysics Geosystems, 5, doi: 10.1029/2003GC000597. 
Schiellerup H (1995) Generation and equilibration of olivine tholeiites in the northern rift zone of Iceland. A petrogenetic study of the Bláfjall table mountain. J Volcanol Geotherm Res 65:161-179.

Schipper CI, Le Voyer M, Moussallam Y, White JDL, Thordarson T, Kimura J-I, Chang Q (2016) Degassing and magma mixing during the eruption of Surtsey Volcano (Iceland, 1963-1967): the signatures of a dynamic and discrete rift propagation event. Bulletin of Volcanology, 78, 33.

Schmidt A, Carslaw KS, Mann GW, Wilson M, Breider TJ, Pickering SJ, Thordarson T (2010) The impact of the 1783-1784 AD Laki eruption on global aerosol formation processes and cloud condensation nuclei, Atmospheric Chemistry and Physics, 10, $6025-6041$.

Shimizu K, Saal AE, Myers CE, Nagel AN, Hauri EH, Forsyth DW, Kamenetsky VS, Niu Y (2016) Two-component mantle melting-mixing model for the generation of mid-ocean ridge basalts: implications for the volatile content of the Pacific upper mantle. Geochimica et Cosmochimica Acta, 176, 44-80.

Shishkina TA, Botcharnikov RE, Holtz F, Almeev RR, Jazwa AM, Jakubiak AA (2014) Compositional and pressure effects on the solubility of $\mathrm{H} 2 \mathrm{O}$ and $\mathrm{CO} 2$ in mafic melts. Chemical Geology, 388, 112-129.

Shishkina TA, Botcharnikov RE, Holtz F, Almeev RR, Portnyagin MV (2010) Solubility of $\mathrm{H} 2 \mathrm{O}$ and $\mathrm{CO} 2$-bearing fluids in tholeiitic basalts pressures up to $500 \mathrm{MPa}$. Chemical Geology, 277, 115-125.

Shorttle O, Maclennan J. (2011) Compositional trends of Icelandic basalts: Implications for short-length scale lithological heterogeneity in mantle plumes. Geochemistry Geophysics Geosystems, 12/11 DOI: 10.1029/2011GC003748 
Sigmarsson O, Haddadi B, Carn S, Moune S, Gudnason J, Yang K, Clarisse L (2013) The sulfur budget of the 2011 Grímsvötn eruption, Iceland. Geophysical Research Letters, 40/23, 6095-6100.

Sigmundsson F, Hooper A, Hreinsdóttir S, Vogfjörd KS, Ófeigsson BG, Heimisson ER, Dumont S, Parks M, Spaans K, Gudmundsson GB, Drouin V, Árnadóttir Th, Jónsdóttir K, Gudmundsson MT, Högnadóttir Th, Fridriksdóttir HM, Hensch M, Einarsson P, Magnússon E, Samsonov S, Brandsdóttir B, White RS, Ágústsdóttir Th, Greenfield T, Green RG, Hjartardóttir AR, Pedersen R, Bennett RA, Geirsson H, La Femina PC, Björnsson H, Pálsson F, Sturkell E, Bean CJ, Möllhoff M, Braiden AK, Eibl EPS (2014) Segmented lateral dyke growth in a rifting event at Bárðarbunga volcanic system, Iceland. Nature, 517, 191-195.

Sigurdsson H (1990) Evidence of volcanic loading of the atmosphere and climate response. Palaeogeography, Palaeoclimatology, Palaeoecology, 89/3, 277-289.

Sigurdsson H, Sparks RSJ (1981) Petrology of rhyolitic and mixed magma ejecta from the 1875 eruption of Askja, Iceland. J Petrol 22:41-84.

Sigurdsson IA, Steinthórsson S, Grönvold K (2000) Calcium-rich inclusions in Cr-spinels from Borgarhraun, northern Iceland. Earth Planet Sci Lett 183:15-26.

Steele-MacInnis MJ, Esposito R, Bodnar RJ (2011) Thermodynamic model for the effect of post-entrapment crystallization on the $\mathrm{H} 2 \mathrm{O}-\mathrm{CO} 2$ systematics of volatile saturated silicate melt inclusions. Journal of Petrology, 52, 2461-2482.

Steinthórsson S, Hardarson BS, Ellam RM, Larsen G (2000) Petrochemistry of the Gjálp1996 subglacial eruption, Vatnajökull, SE Iceland. J Volcanol Geotherm Res 98:79-90.

Sterner SM, Pitzer KS (1994) An equation of state for carbon dioxide valid from zero to extreme pressures. Contributions to Mineralogy and Petrology, 117, 362-374 
Thordarson T, Self S (2003) Atmospheric and environmental effects of the 1783-1784 Laki eruption: A review and reassessment. Journal of Geophysical Research Atmosphere, $108,1-29$

Thordarson T, Self S, Miller DJ, Larsen G, Vilmundardóttir EG (2003) Sulphur release from flood lava eruptions in the Veiðivötn, Grímsvötn and Katla volcanic systems, Iceland. Geological Society London Special Publication, 213, 103-121.

Thordarson T, Miller DJ, Larsen G, Self S, Sigurdsson H (2001) New estimates of sulfur degassing and atmospheric mass-loading by the 934 AD Eldgjá eruption, Iceland. Journal of Volcanology and Geothermal Research, 108, 33-54.

Tollari N, Baker DR, Barnes S-J (2008) Experimental effects of pressure and fluorine on apatite saturation in mafic magmas, with reference to layered intrusions and massif anorthosites. Contributions to Mineralogy and Petrology, 156, 161-175.

Trønnes RG (1990) Basaltic melt evolution of the Hengill volcanic system, SW Iceland, and evidence for clinopyroxene assimilation in primitive tholeiitic magmas. J Geophys Res 95:15893-15910.

Urann BM, Le Roux V, Hammond K, Marschall HR, Lee C-TA, Monteleone BD (2017) Fluorine and chlorine in mantle minerals and the halogen budget of the Earth's mantle. Contributions to Mineralogy and Petrology 172, 51-

Viti C, Frezzotti ML (2001) Transmission electron microscopy applied to fluid inclusion investigations. Lithos, 55, 125-138.

Vogfjörð KS, Hensch M, Hjörleifsdóttir V, Jónsdóttir K (2015) High-precision mapping of seismcity in the last decades at Bárðarbunga volcano. EGU Conference Abstracts $17: 13430 \mathrm{~V}$. 
Webster JD, Kinzler RJ, Mathez EA (1999) Chloride and water solubility in basalt and andesite melts and implications for magmatic degassing. Geochimica et Cosmochimica Acta, 63/5, 729-738.

Werner R (1994) Struktur und Entstehung subglazialer/subakustrischer Vulkane am Beispiel des Vulkankomplexes Herdubreid/Herdubreidartögl in Island. $\mathrm{PhD}$ thesis, ChristianAlbrechts-Universität zu Kiel, 153p.

White WM (2013) Geochemistry. Wiley-Blackwell, pp 659.

Workman RK, Hart SR (2005) Major and trace element composition of the depleted MORB mantle (DMM). Earth and Planetary Science Letters, 231, 53-72.

Workman RK, Hauri E, Hart SR, Wang J, Blusztajn J (2006) Volatile and trace elements in basaltic glasses from Samoa: Implications for water distribution in the mantle. Earth and Planetary Science Letters, 241, 932-951. 


\section{FIGURE CAPTIONS:}

Fig. 1. a) Map of the 2014-2015 Holuhraun lava field, showing the locations of sampling sites. Insert shows the location within the active rift zone of Iceland. NVZ-Northern Volcanic Zone, EVZ-Eastern Volcanic Zone, WVZ-Western Volcanic Zone, RVZ-Reykjanes Volcanic Zone.

b) Estimated effusion rate during the course of eruption based on Bony et al. (2017). Figure also contains the identifiers (e.g.: H14) of the studied samples pointing out the collection dates.
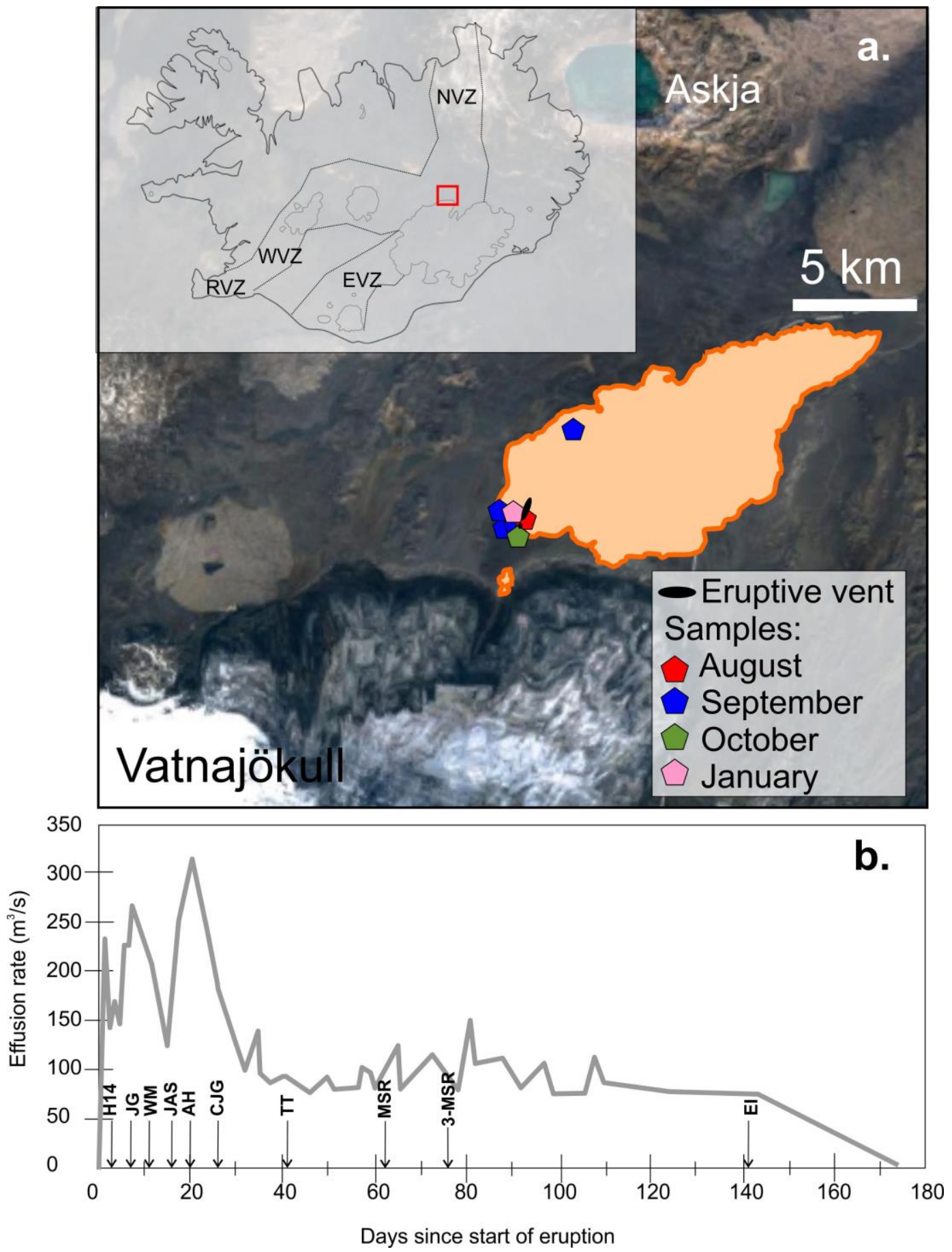
Fig. 2. Textures of silicate melt and fluid inclusions in clinopyroxene and plagioclase macrocrysts from the 2014-2015 Holuhraun eruption.

a) Photomicrograph of a spherical melt inclusion in plagioclase containing a $\mathrm{CO}_{2}$-rich vapour bubble.

b) Back-scattered electron (BSE) image of a plagioclase macrocryst with a melt inclusion-rich core and an inclusion-free rim.

c) Melt and fluid inclusions trapped in a plagioclase core showing heterogeneous entrapment, indicating the presence of an immiscible fluid phase.

d) BSE image of a plagioclase macrocryst with melt inclusion-rich rim. Note the presence of mineral inclusions.

e) Photomicrograph of pseudosecondary fluid and melt inclusion rows in a plagioclase core.

f) Photomicrograph of randomly distributed fluid inclusions in plagioclase.

g) BSE image of tephra containing sulphide blebs in the groundmass and enclosed in a clinopyroxene (cpx) microphenocryst. Ol-olivine, Plag-plagioclase. 


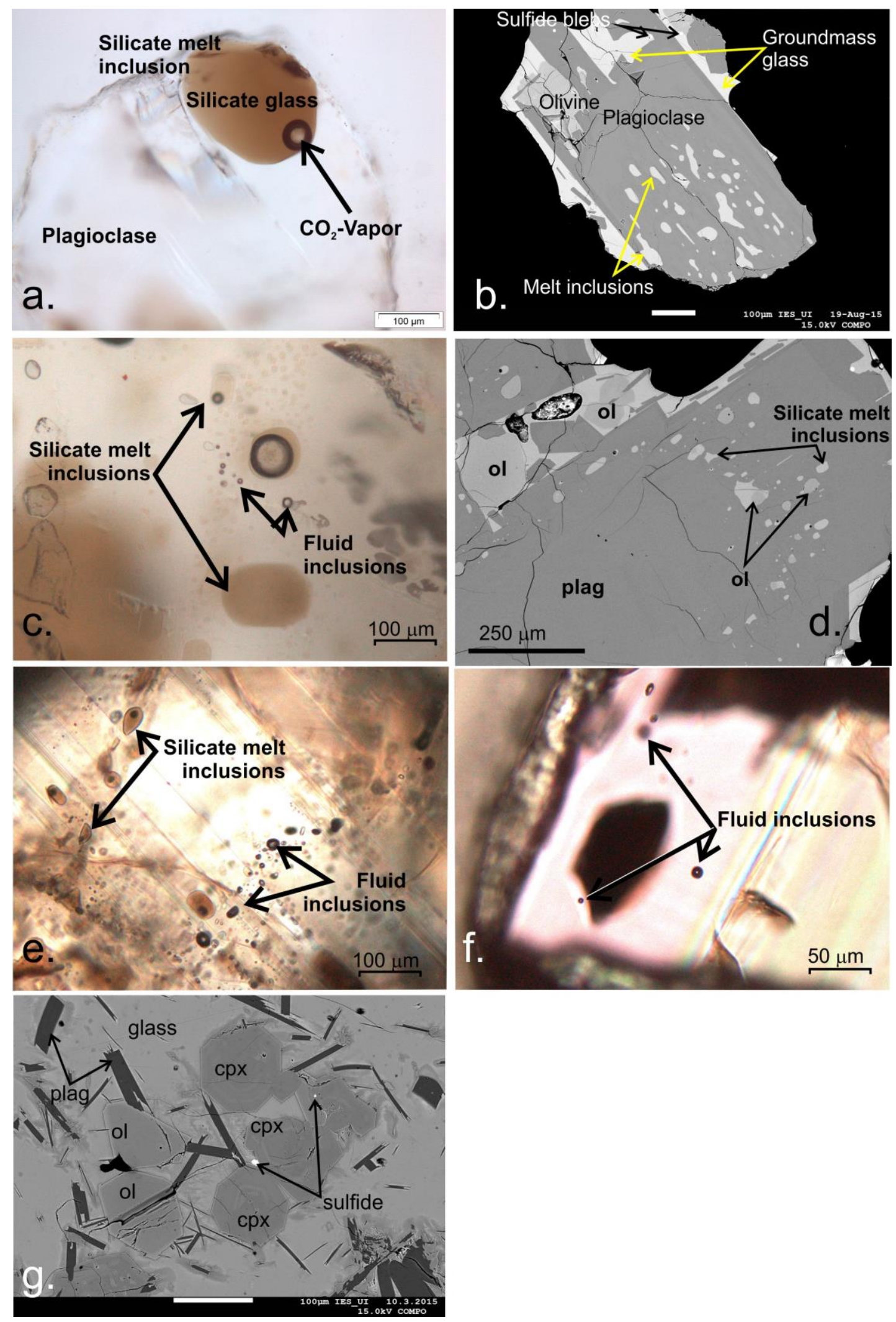


Fig. 3. Variation of major and selected trace elements in groundmass glass and melt inclusions corrected for post-entrapment crystallization. Figures also contain liquid lines of descent calculated at $0.3 \mathrm{GPa}$ (black arrow) and $0.1 \mathrm{GPa}$ (gray arrow), using the average composition of the most primitive melt inclusions as a starting composition (dotted arrows - based on mineral-melt models of Langmuir et al., 1992, full arrows-based on mineral-melt models of Danyushevsky, 2002, for details see supplementary material). Bulk rock composition (Halldórsson et al., this issue), Bárðarbunga Holocene tephra glass (Óladóttir et al., 2011) and a compilation of Icelandic tholeiitic glasses are also shown (Breddam, 2002, Condomines et al., 1983, Gurenko and Chaussidon 1995, Hansteen, 1991, Meyer, 1985, Risku-Norja, 1985, Schiellerup, 1995, Sigurdsson and Sparks, 1981, Sigurdsson et al., 2000, Steinthórsson et al., 2000, Trønnes, 1990, Werner, 1990, Nordic Volcanological Center unpublished basalt glass analyses). Plag-plagioclase, Cpx-clinopyroxene, Ol-olivine. Error bars indicate $2 \mathrm{~s}$ uncertainty. 

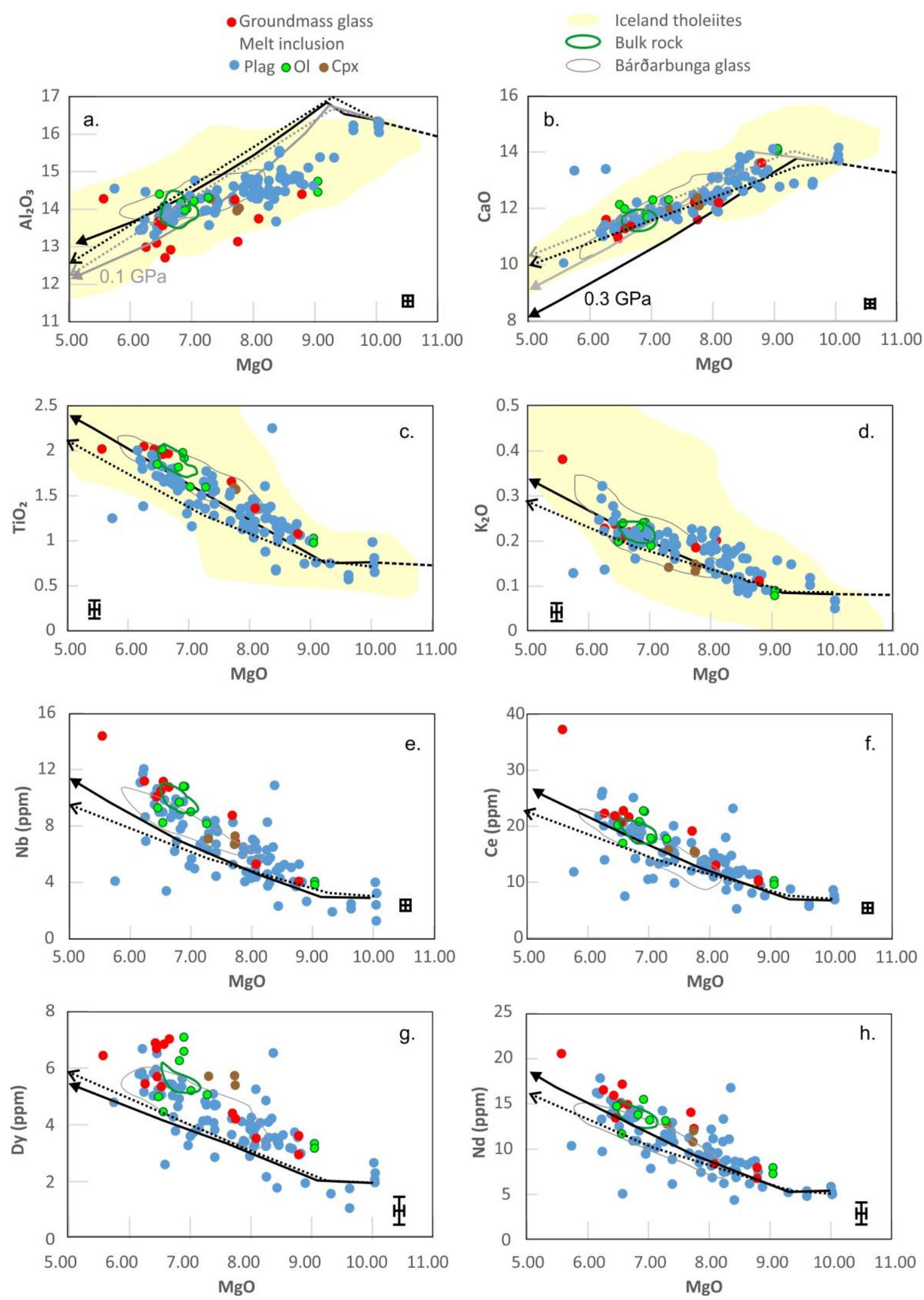
Fig. 4. $\mathrm{CO}_{2}$ concentrations in Holuhraun melt inclusions and matrix glasses as a function of their $\mathrm{MgO}$ (a), $\mathrm{Nb}(\mathrm{b})$ and $\mathrm{H}_{2} \mathrm{O}$ (d) contents; and the variation of $\mathrm{CO}_{2} / \mathrm{Nb}$ ratios in the same glasses as a function of their Mg\# (c). $\mathrm{Mg \#}$ calculated as $100 * \mathrm{MgO}(\mathrm{mol}) /(\mathrm{MgO}(\mathrm{mol})+\mathrm{FeO}(\mathrm{t})(\mathrm{mol}))$. The field of undegassed melt compositions in figure (b) and (c) was calculated based on the studies of Hauri et al. (2002) and Rosenthal et al. (2015). Fractional crystallisation trends in (a) are determined by the similar behaviour of $\mathrm{Nb}$ and $\mathrm{CO}_{2} . \mathrm{Nb}$ concentrations calculated along a liquid line of descent (see supplementary material) were multiplied by the assumed primary $\mathrm{CO}_{2} / \mathrm{Nb}$ values of 505 and 314. Numbers next to arrows in (a) indicate the maximum $\mathrm{CO}_{2}$ contents in melt inclusions from Laki (Hartley et al. 2014) and the $10 \mathrm{ka}$ Grímsvötn tephra series (Neave et al. 2015). Gray dashed lines in figure (d) are $\mathrm{CO}_{2}$ solubilities at 0.4 and $0.5 \mathrm{GPa}$ calculated by VolatileCalc (Newman and Lowenstern, 2002). Open symbols in the same figure indicate measurements by FTIR spectroscopy. Note the only $\mathrm{CO}_{2}$-rich melt inclusion with $\sim 3900 \mathrm{ppm} \mathrm{CO}_{2}$ is shown only in (c) and (d).
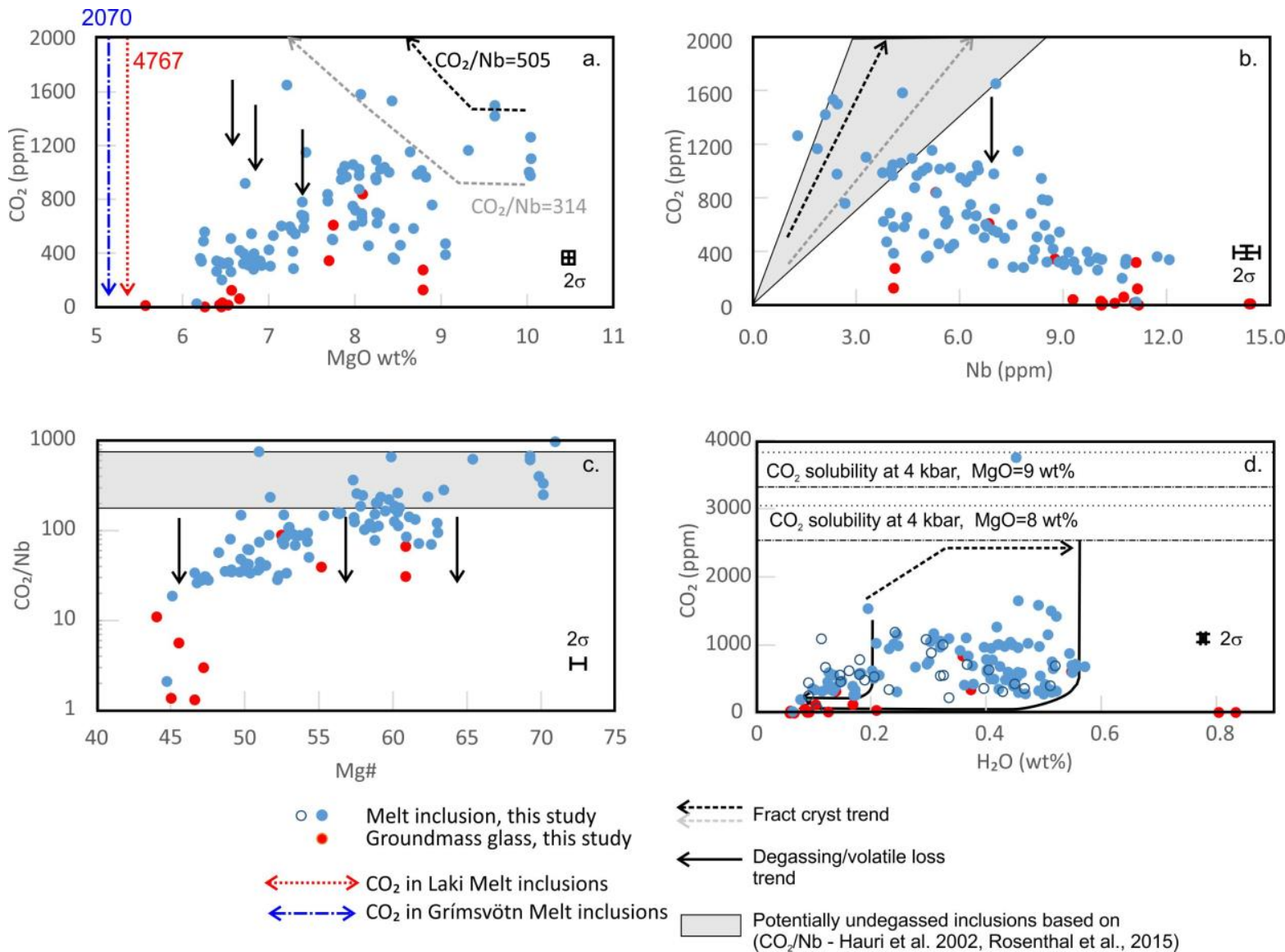
Fig. 5. $\mathrm{H}_{2} \mathrm{O}$ concentrations in Holuhraun melt inclusions and matrix glasses as a function of major and trace element contents (a-c); $\mathrm{H}_{2} \mathrm{O} / \mathrm{Ce}$ ratios as a function of $\mathrm{Mg} \#$ (d). Diamonds are analyses from samples collected during the first 10 days of the eruption; circles are from samples collected later. Fractional crystallisation trends in (a) and (b) are determined by the similar behaviour of $\mathrm{Ce}$ and $\mathrm{H}_{2} \mathrm{O}$ during crystallisation. Ce concentrations calculated along a liquid line of descent (see supplementary material) were multiplied by $\mathrm{H}_{2} \mathrm{O} / \mathrm{Ce}$ values of 253 and 180. Gray fields in (c) and (d) indicate the MORB field (Michael, 1995). Comparative $\mathrm{H}_{2} \mathrm{O}$ concentrations are from Hartley et al. (2014) and Neave et al. (2015).
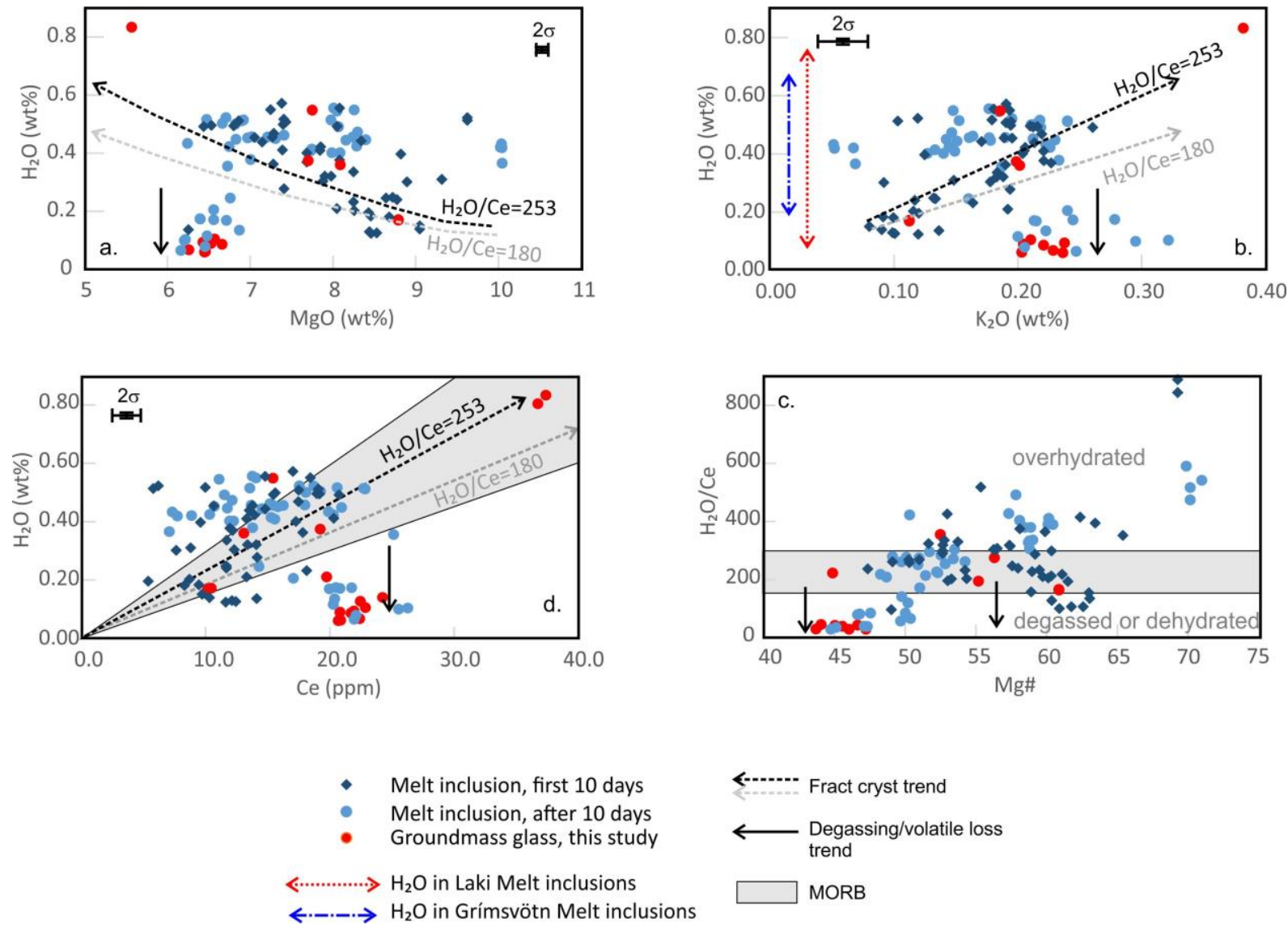
Fig. 6. Variation of $\mathrm{Cl}$ contents (a) and $\mathrm{Cl} / \mathrm{K}$ ratios (b) and (c) in Holuhraun melt inclusions and matrix glasses. Red open symbols show analyses made by electron microprobe at the University of Cambridge; filled symbols show analyses from the University of Iceland. Melt inclusion and groundmass glass compositions measured by Gauthier et al. (2016) from samples collected in the first 10 days are shown for comparison. MORB compositional range and E- and N-MORB Cl/K values are from Shimizu et al. (2016). Fractional crystallisation trends in figure (a) are determined by the similar behaviour of $\mathrm{K}$ and $\mathrm{Cl}$ during crystallisation. $\mathrm{K}$ concentrations calculated along a liquid line of descent (see supplementary material) were multiplied by the assumed primary $\mathrm{Cl} / \mathrm{K}$ values of 0.02 and 0.08 . Gray error bar in figure (a) is $2 \sigma$ uncertainty estimated for melt inclusions with less than 40 ppm Cl, black error bars are valid for more Cl-rich compositions.
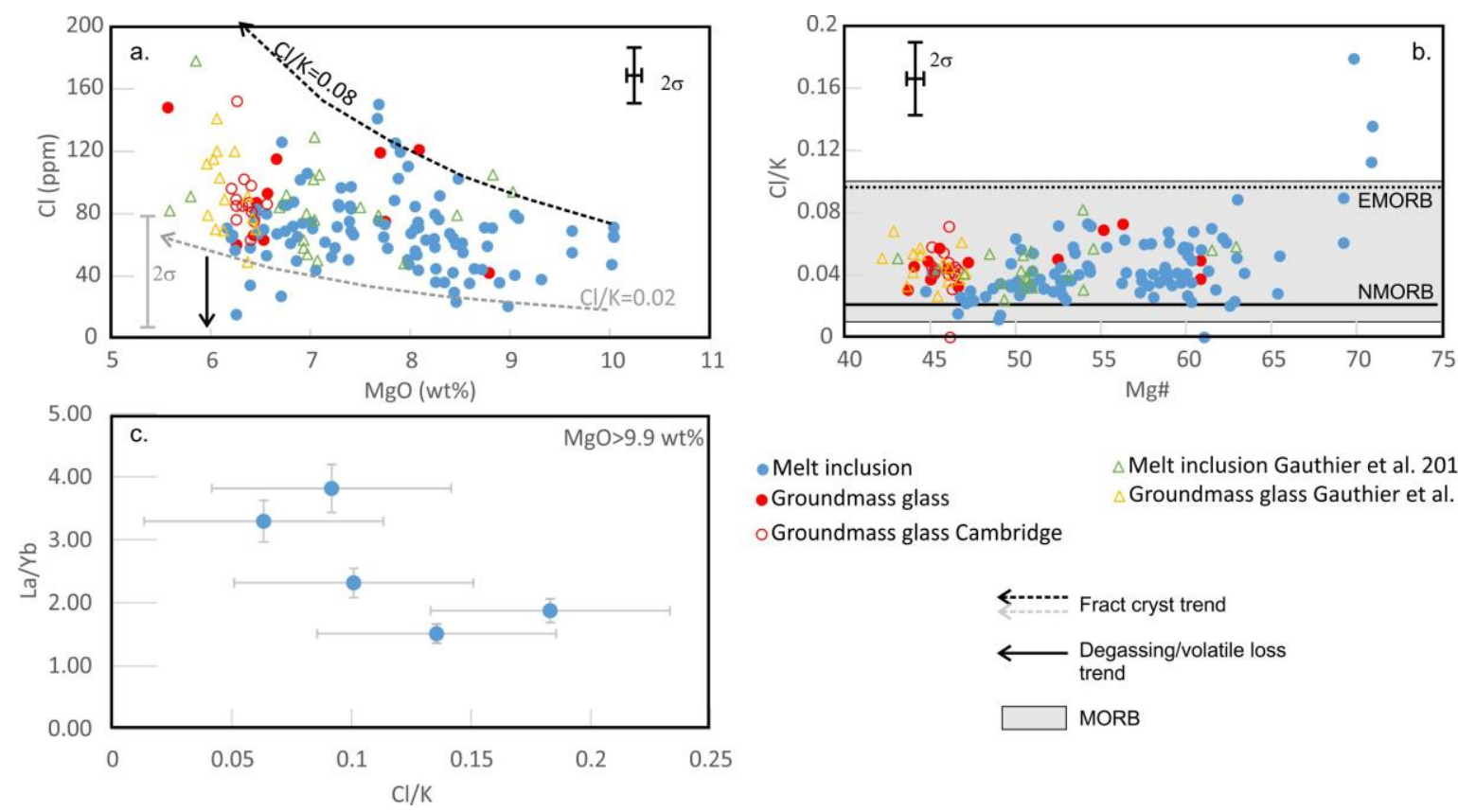

- Melt inclusion

- Groundmass glass

$\triangle$ Melt inclusion Gauthier et al. 2016

- Groundmass glass Cambridge

(-..-... Fract cryst trend

$\longleftarrow$ Degassing/volatile loss

MORB 
Fig. 7. Variation of F contents (a) and (b) and F/Nd ratios (c) in Holuhraun melt inclusions and matrix glasses. Red open symbols show analyses made by electron microprobe at the University of Cambridge; filled symbols are SIMS analyses. Diamonds are analyses of plagioclase-hosted melt inclusions collected during the first 10 days of the eruption; circles are from samples collected later. Melt inclusion and groundmass glass compositions analysed by Gauthier et al. (2016) from samples collected in the first 10 days are shown for comparison. MORB compositional range and E- and N-MORB F/Nd values are from Shimizu et al. (2016). Fractional crystallisation trends in (a) were calculated along a liquid line of descent (see in Supplementary material) and $\mathrm{Nd}$ contents were multiplied by $\mathrm{F} / \mathrm{Nd}$ ratios deduced from groundmass glasses and olivine- and clinopyroxene-hosted melt inclusions (see text).
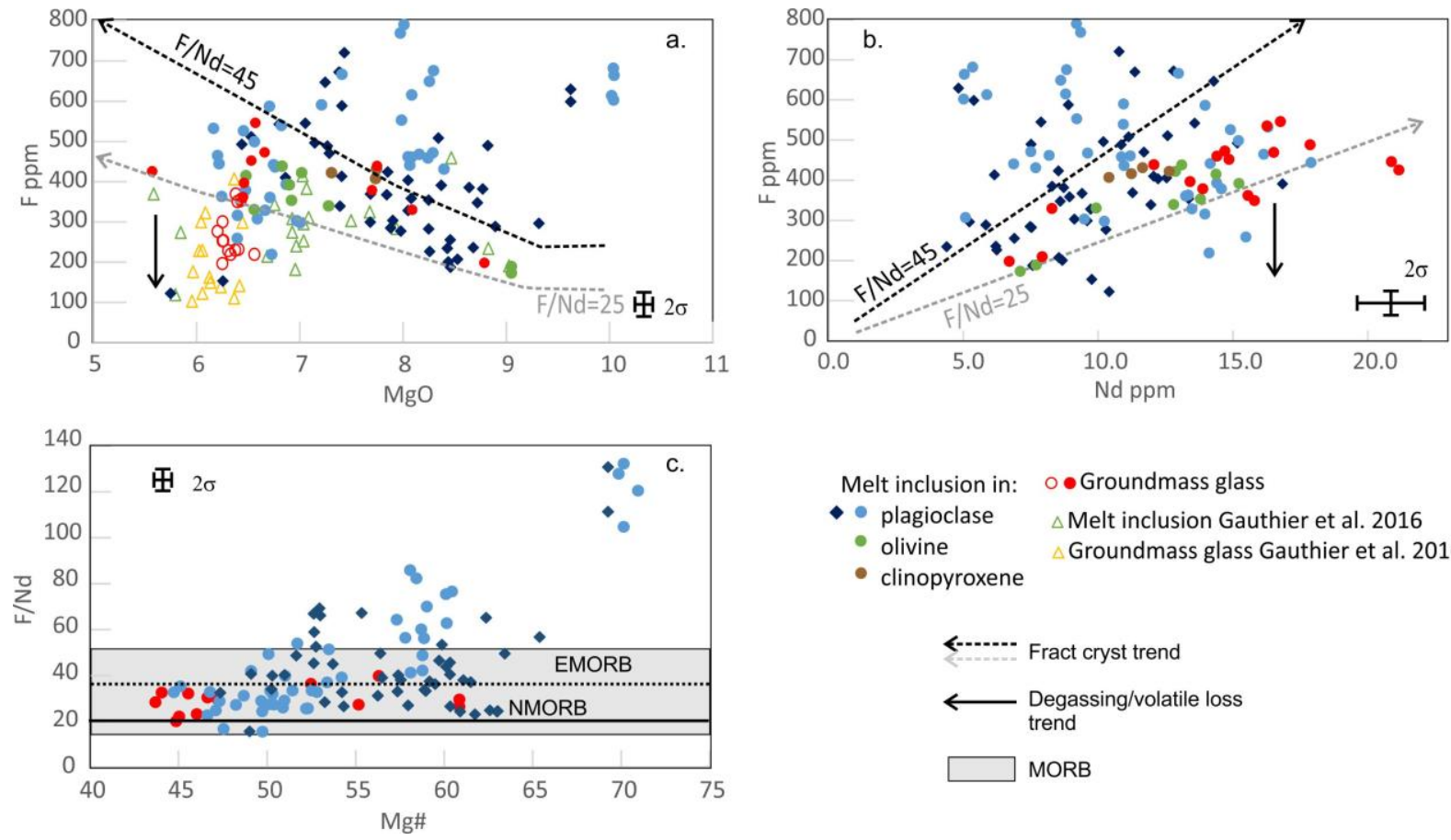

Melt inclusion in: $\circ \bullet$ Groundmass glass

- plagioclase $\triangle$ Melt inclusion Gauthier et al. 2016

- olivine $\quad$ Groundmass glass Gauthier et al. 2016

- clinopyroxene

Fract cryst trend

$\longleftarrow$ Degassing/volatile loss

MORB 
Fig. 8: Variation of S contents (a) and S/Dy ratios (b) in Holuhraun melt inclusions and matrix glasses. Red open symbols show analyses made by electron microprobe at the University of Cambridge; filled symbols show analyses from the University of Iceland. Melt inclusion and groundmass glass compositions analysed by Gauthier et al. (2016) from samples collected in the first 10 days are shown for comparison. MORB compositional range and E- and N-MORB S/Dy values are from Shimizu et al. (2016). For fractional crystallisation trends in figure (a) Dy contents were calculated along a liquid line of descent (see in Supplementary material) and were multiplied by 220 and 350 S/Dy ratios deduced from glass compositions without significant S-excess or degassing. Sulphur saturation calculated at $0.12 \mathrm{GPa}$, by the model of Ariskin et al. (2013) is also shown for two different oxygen fugacities. Comparative data are from Sigmarson et al. (2013), Métrich et al. (1991), Thordarson et al. (2001). Gray error bar in figure (b) is $2 \sigma$ uncertainty estimated for the most primitive melt inclusions with less than $3 \mathrm{ppm}$ of Dy, black error bars are valid for more Dy-rich compositions
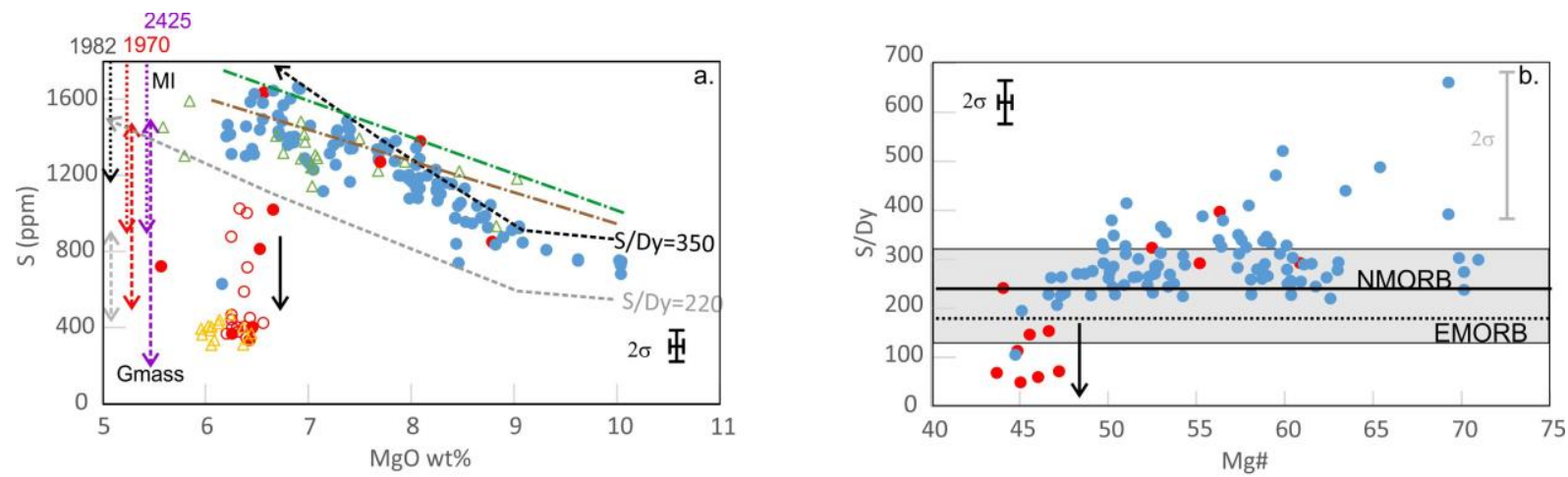

- Groundmass glass

o Groundmass glass Cambridge

$\triangle$ Groundmass glass Gauthier et al. 2016

-Melt inclusion

$\Delta$ Melt inclusions Gauthier et al. 2016

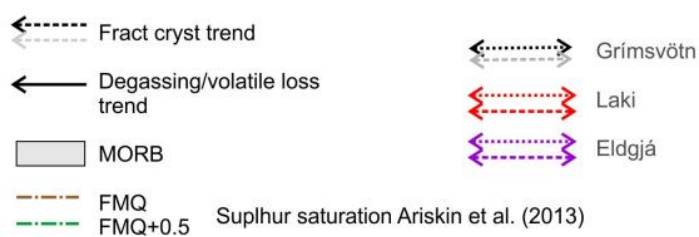


Fig. 9: Comparison of thermobarometric calculations in Holuhraun melt and fluid inclusions and groundmass glasses. All pressures are calculated using PEC-corrected melt inclusion compositions. Figure (a) compares the variation of pressures calculated based on volatile saturation derived from the VolatileCalc model (Newman and Lowenstern, 2002) to the results of OPAM (olivine-plagioclase-augite-melt) barometry (Yang et al., 1996) and cpx-melt barometry (Neave and Putirka, 2017). The results of these two latter barometers are discussed in two accompanying papers in this issue (Halldórsson et al. and Hartley et al.). Figure (b) compares the result of VolatileCalc and OPAM parameterisations as a function of MgO content in the melt inclusions. The most evolved melt inclusions show similar pressures by both barometers within uncertainty. Differences are larger among the moderately to highly primitive melt inclusions. Volatile saturation pressures generally coincide with the depth of dyke intrusion (Sigmundsson et al., 2015), whereas OPAM barometry results coincide with depth of a deflation source beneath the Bárðarbunga caldera determined by geophysical methods (Guðmundsson et al. 2016). Some OPAM pressures among the primitive melt inclusions coincide with the depth of deep earthquakes observed in the last couple of years ESE of the Bárðarbunga caldera (Vogfjörd et al., 2015, Hudson et al., 2017) and have been attributed to deep magma movement.
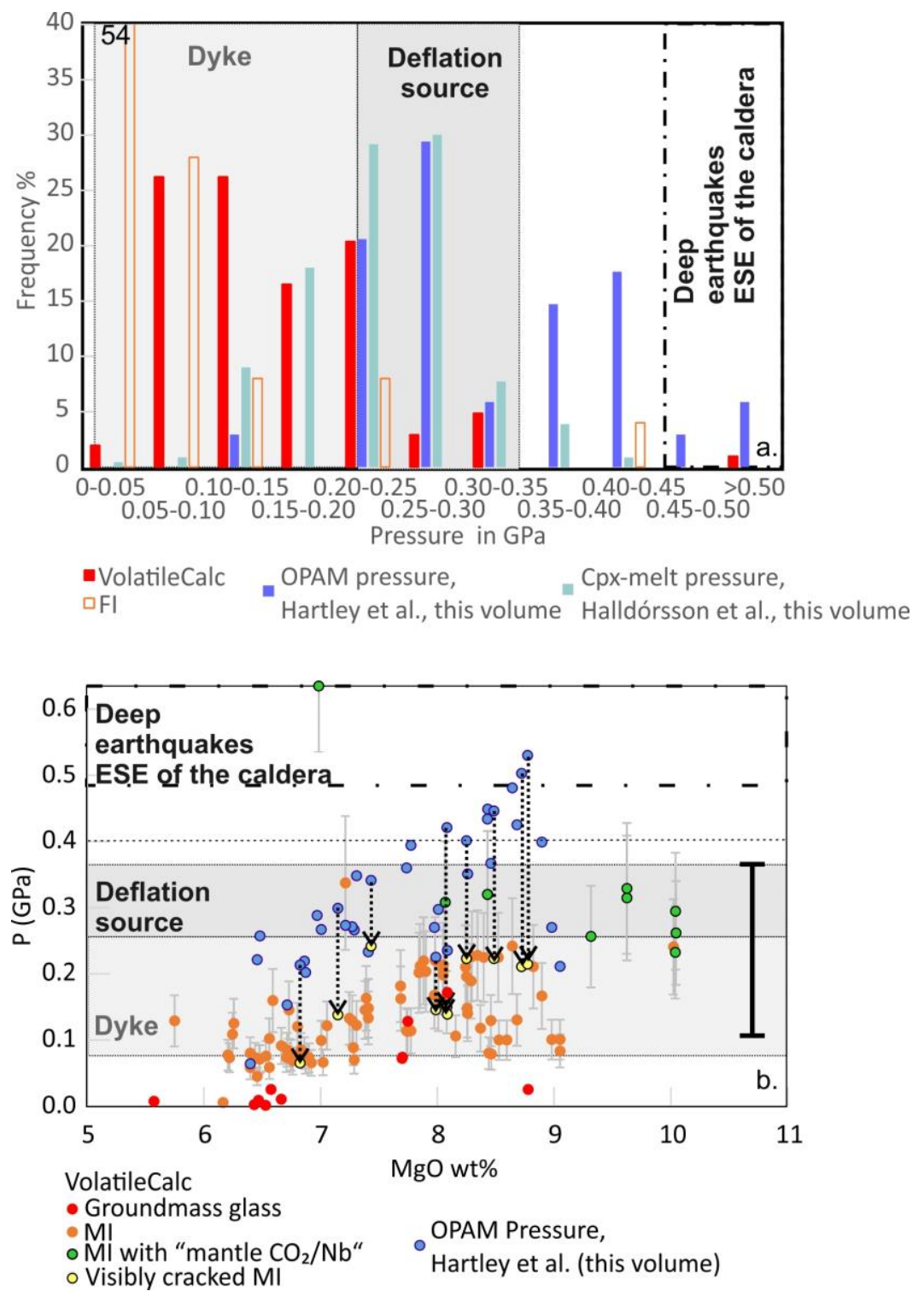
Fig. 10. Degassing history of the Holuhraun magma. Cumulative $\mathrm{CO}_{2}$ mass release from the Holuhraun magma, calculated using either $\mathrm{Nb}$ or $\mathrm{Ba}$ as a proxy to predict undegassed $\mathrm{CO}_{2}$ contents for each melt inclusion and associating each inclusion with a mass of melt. (a) Cumulative $\mathrm{CO}_{2}$ mass release vs. mass fraction crystallized, where $\mathrm{F}=1$ is defined as the composition of the Holuhraun carrier melt at the time of eruption. (b) Cumulative $\mathrm{CO}_{2}$ mass release vs. pressure. Melt inclusion OPAM equilibration pressures (Hartley et al. this issue) indicate a near-continuous degassing rate between $\sim 4.2$ and $1.5 \mathrm{kbar}$. (c) Syn-eruptive volatile fluxes calculated based on the magma discharge rates of Bony et al. (2017) and average degassing rate determined in this study. Volatile fluxes are compared to the results of field measurements (Gíslason et al. 2015).
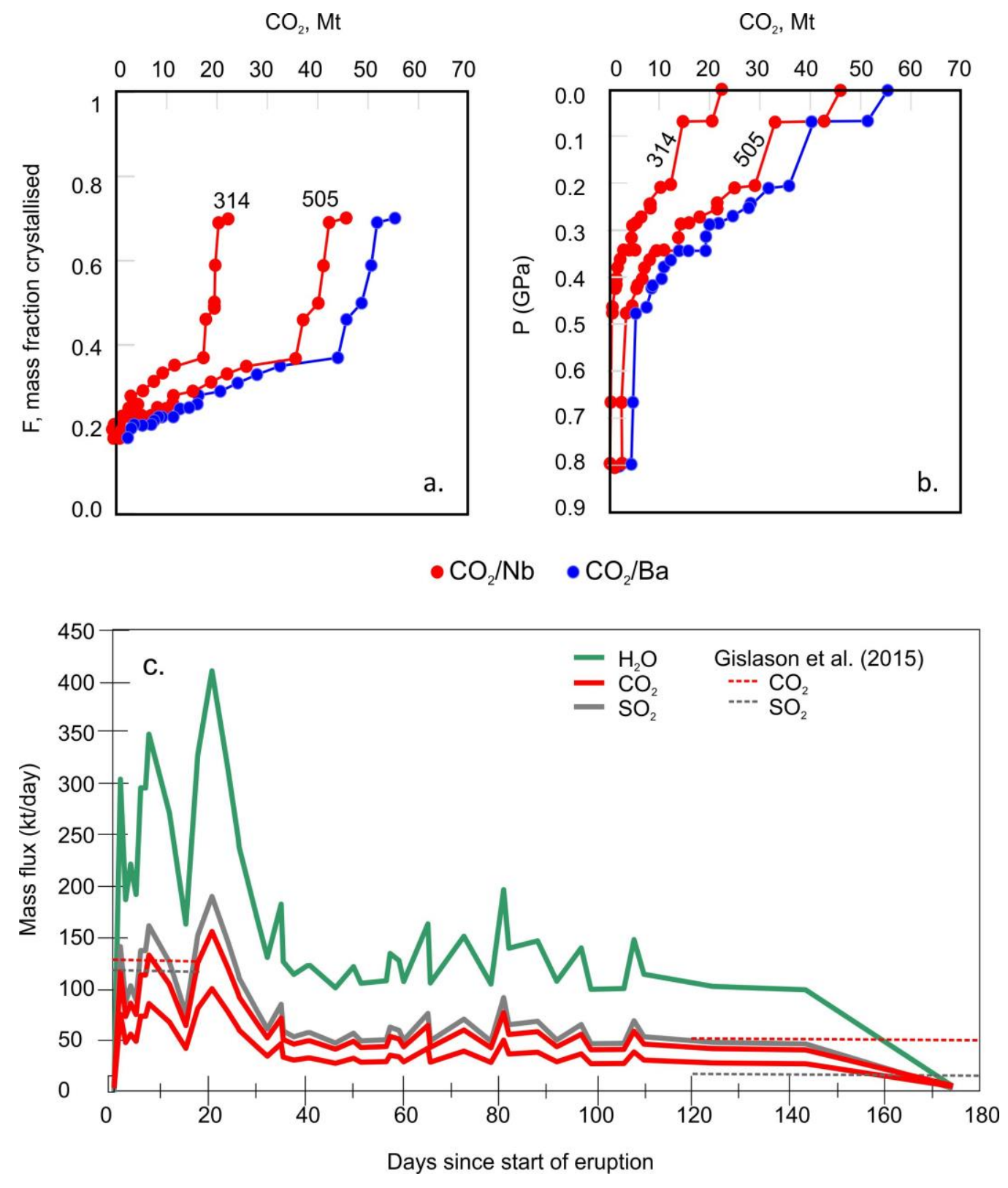


\section{TABLES:}

Table 1: Volatile composition of primary melt and magma source(s) calculated with the assumption that the Holuhraun parental melt was produced by $15 \%$ modal batch melting (Supplementary material). Bulk partition coefficients $\left(\mathrm{D}_{0}\right)$ are from Rosenthal et al. (2015) $\mathrm{CO}_{2}$; Hirschmann et al. (2009) - $\mathrm{H}_{2} \mathrm{O}$; Dalou et al. (2009) - Cl, F; Workman and Hart (2005) - Dy.

\begin{tabular}{|l|l|l|l|}
\hline Volatile & Do & Volatiles in primary & Volatiles in Mantle \\
& & melt $(\mathbf{p p m})$ & $(\mathbf{p p m})$ \\
\hline $\mathrm{CO}_{2}$ & 0.00055 & $848-1364$ & $128-205$ \\
\hline $\mathrm{H}_{2} \mathrm{O}$ & 0.0065 & $1200-1700$ & $187-264$ \\
\hline $\mathrm{Cl}$ & & & $2-8(15)$ \\
\hline $\mathrm{F}$ & 0.0015 & $13-51(102)$ & $20-37$ \\
\hline $\mathrm{S}$ & 0.011 & $128-230$ & $93-203$ \\
\hline
\end{tabular}


Table 2: Comparison of estimated volatile release during the 2014-2015 Holuhraun eruption and two of the large historic flood basalt eruptions of Iceland. Laki data from Hartley et al. (2014) and Métrich et al. (1991), Eldgjá - Thordarson et al. (2001). $\mathrm{CO}_{2}$ release (*) is calculated from the estimated syn-eruptive $\mathrm{CO}_{2}$ release and not by the total $\mathrm{CO}_{2}$ budget, which is significantly higher (see text).

\begin{tabular}{|c|c|c|c|c|c|c|c|c|}
\hline & Holuhraun, & $2014-2015$ & & Laki, 17 & $3-84$ & & Eldgjá & $4-940$ \\
\hline & $\begin{array}{l}\text { Total syn- } \\
\text { eruptive } \\
\text { volatile } \\
\text { release, this } \\
\text { study (Mt) }\end{array}$ & $\begin{array}{c}\text { Total syn- } \\
\text { eruptive } \\
\text { volatile } \\
\text { release, field } \\
\text { measurement } \\
\text { (Mt) }\end{array}$ & $\begin{array}{c}\text { Daily } \\
\text { release, } \\
\text { this study } \\
(\mathrm{Mt})\end{array}$ & $\begin{array}{c}\text { Total } \\
\text { release } \\
(\mathrm{Mt})\end{array}$ & $\begin{array}{l}\text { Estimat } \\
\text { release }\end{array}$ & $\begin{array}{l}\text { daily } \\
\text { t) }\end{array}$ & $\begin{array}{r}\text { Total } \\
\text { release } \\
(\mathrm{Mt})\end{array}$ & $\begin{array}{l}\text { Daily } \\
\text { release } \\
(\mathrm{Mt})\end{array}$ \\
\hline & & & & & average & $\begin{array}{l}1^{\text {st }} 1.5 \\
\text { months }\end{array}$ & & \\
\hline $\mathrm{H}_{2} \mathrm{O}$ & 22.2 & 284 & 0.12 & 238 & 0.98 & 3.17 & n.a. & n.a. \\
\hline $\mathrm{CO}_{2}$ & $5.9-7.2$ & 5.6 & 0.08 & 304 & 1.25 & 4.05 & n.a. & n.a. \\
\hline $\mathrm{SO}_{2}$ & 11.3 & 11.8 & 0.06 & 122 & 0.50 & 1.63 & 219 & 0.10 \\
\hline $\mathrm{HCl}$ & b.d. & b.d. & b.d. & 7 & 0.03 & 0.09 & n.a. & n.a. \\
\hline $\mathrm{HF}$ & b.d. & b.d. & b.d. & 15 & 0.06 & 0.20 & n.a. & n.a. \\
\hline
\end{tabular}

